\title{
Financial Intermediaries, Credit Shocks and Business Cycles
}

\author{
Yasin Mimir \\ Istanbul School of Central Banking \\ Central Bank of the Republic of Turkey ${ }^{1}$
}

\begin{abstract}
I document the cyclical properties of aggregate balance sheet variables of the U.S. commercial banking sector: (i) Bank credit and deposits are less volatile than output, while net worth and leverage ratio are several times more volatile, (ii) bank credit and net worth are procyclical, while deposits, leverage ratio and loan spread are countercyclical. I then present an equilibrium real business cycle model with a financial sector to investigate how the dynamics of macroeconomic aggregates and balance sheet variables of U.S. banks are influenced by empirically-disciplined shocks to bank net worth. I find that these financial shocks are important not only for explaining the dynamics of financial flows but also for the dynamics of standard macroeconomic variables observed in the U.S. data. The simulation of the model shows that the recent deterioration in aggregate net worth of U.S. banking sector contributed significantly to the 2007-09 recession. The model-construct tightness measure of credit conditions tracks quite well the FED Board's index of credit tightening in the last three recessions of the U.S economy implying that the Lagrange multipliers attached to the financial constraints in dynamic stochastic general equilibrium models with credit frictions might contain valuable real-time information about the financial conditions of an economy.
\end{abstract}

Keywords: Banks, Credit Frictions, Financial Shocks, Macro-Financial Fluctuations

\section{Introduction}

What are the cyclical properties of aggregate balance sheet variables of the U.S. banking sector? ${ }^{2}$ How important are financial shocks relative to standard productivity shocks in driving real and financial business cycles in the U.S.? To address these questions, this study proposes an equilibrium real business cycle model with a financial sector, that is capable of matching the fluctuations in both standard macroeconomic aggregates and balance sheet variables of the banking sector observed in the U.S. data. Although a growing body of literature studies the relevance of financial shocks together with an explicit modeling of frictions in financial sector, the behavior of aggregate financial variables in the U.S. banking sector and how they interact

\footnotetext{
${ }^{1}$ Fener Kalamıs Cad. Atlıhan Sok. No:30/A Kadıköy, Istanbul, Turkey. Telephone number: +90 216542 3122. E-mail address: yasin.mimir@tcmb.gov.tr.

${ }^{2}$ Throughout the paper, I use the terms "aggregate balance sheet variables", "aggregate financial flows", and "financial variables" interchangeably.
} 
with real variables over the business cycle have not been fully explored in the literature. ${ }^{3}$ Most previous studies have not tried to match fluctuations in both standard macro variables and aggregate balance sheet variables of the U.S. banking sector simultaneously. In this paper, I show that financial shocks to the banking sector contribute significantly to explaining the observed dynamics of real and financial variables. Financial shocks play a major role in driving real fluctuations due to their impact on the tightness of bank capital constraint and hence credit spread.

I first systematically document the business cycle properties of aggregate financial variables, using the data on the U.S. commercial banks from the Federal Reserve Board. ${ }^{4}$ The following empirical facts emerge from the analysis: (i) Bank credit, deposits, and loan spread are less volatile than output, while net worth and leverage ratio are more volatile, (ii) bank assets and net worth are procyclical, while deposits, leverage ratio, and loan spread are countercyclical, and (iii) financial variables lead the output fluctuations by one to three quarters.

I then assess the quantitative performance of a theoretical model by its ability to match these empirical facts. In particular, there are two main departures from an otherwise standard real business cycle framework. The first departure is that I introduce an active banking sector with financial frictions into the model, which are modeled as in Gertler and Karadi (2011). Financial frictions require that banks borrow funds from households and their ability to borrow is limited due to a moral hazard (costly enforcement) problem, inducing an endogenous capital constraint for banks in obtaining deposits. ${ }^{5}$ This departure is needed in order to have balance sheet fluctuations of financial sector matter for real fluctuations. The second departure is that the model incorporates shocks to bank net worth (i.e. "financial shocks") that alter the ability of banks to borrow and to extend credit to non-financial businesses. ${ }^{6}$ Hancock, Laing and

\footnotetext{
${ }^{3}$ See Christiano et. al. (2010), Dib (2010), Meh and Moran (2010), Gertler and Kiyotaki (2010), Gertler and Karadi (2011), Kollman et al. (2011). These papers don't explicitly study the cyclical properties of the aggregate balance sheet variables of the U.S. banking sector over the business cycle.

${ }^{4}$ I also document the business cycle properties of aggregate financial variables of the whole U.S. financial sector from 1952 to 2009, using the Flow of Funds data. The results are available from the author upon request.

${ }^{5}$ Hellmann, Murdock and Stiglitz (2000) argue that moral hazard in banking sector plays a crucial role in most of the U.S. economic downturns in the last century. Moreover, the presence of the agency problem makes the balance sheet structure of financial sector matter for real fluctuations, invalidating the application of ModiglianiMiller theorem to the model economy presented below.

${ }^{6}$ In the context of the theoretical model in this paper, the net worth shock can be interpreted as a redistribution shock, which transfers some portion of the wealth from financial intermediaries to households. However, because of the moral hazard problem between households and bankers, it distorts intermediaries' role of allocating resources between households and firms, inducing large real effects. A complete model of the determination of the
} 
Wilcox (1995), Peek and Rosengren (1997, 2000) empirically show that adverse shocks to bank capital contributed significantly to the U.S. economic downturns of the late 1980s and early 1990s. Theoretically, Meh and Moran (2010) consider shocks that produce sudden shortages in bank capital and originate within the banking sector and argue that they reflect periods of financial distress and weakness in financial markets. Brunnermeier and Pedersen (2009) introduce shocks to bank capital and interpret them as independent shocks arising from other activities like investment banking. Curdia and Woodford (2010) consider exogenous shocks that generate increases in the fraction of loans that are not repaid and in real financial intermediation costs, reducing banks' net worth. Mendoza and Quadrini (2010) study the effect of net worth shocks on asset prices and interpret these shocks as unexpected loan losses due to producers' default on their debt. Iacoviello (2014) argues that 1990-91 and 2007-09 recessions can be characterized by situations in which some borrowers pay less than contractually agreed upon and financial institutions that extend loans to these borrowers suffer from loan losses, resulting in a redistribution of wealth between borrowers and lenders. However, the specific type of the shock I introduce is different from these studies and none of these papers considers the quantitative contribution of net worth shocks in explaining business cycle fluctuations of macroeconomic variables and aggregate financial flows of the U.S. banking sector.

I construct the time series of financial shocks as the residuals from the law of motion for bank net worth, using empirical data for credit spread, leverage ratio, deposit rate and net worth. This approach is similar to the standard method for constructing productivity shocks as Solow residuals from the production function using empirical series for output, capital and labor. ${ }^{7}$ The resulting shock series show that U.S. economy is severely hit by negative financial shocks in the Great Recession. Finally, in order to elucidate the underlying mechanism as clearly as possible, I abstract from various real and nominal rigidities that are generally considered in medium scale DSGE models such as Christiano et. al.(2005) and Smets and Wouters (2007). We also abstract from various types of shocks usually incorporated into the medium scale models. The way that our shock series are constructed makes them independent of the number of shocks added into

fluctuations in net worth of banks is beyond the scope of this study, because my goal is to analyze the quantitative effects of movements in net worth of financial sector on business cycle fluctuations of real and financial variables.

${ }^{7} \mathrm{I}$ also consider some alternative measures of financial shocks, including the one constructed based on loan losses incurred by U.S. commercial banks (using the charge-off and delinquency rates data compiled by the Federal Reserve Board). The construction of these alternative measures and their simulation results are available upon request. The main results of the study do not change under these alternative measures. 
the model.

Using a parsimonious model with standard productivity and bank net worth shocks, I obtain three main results. First, the benchmark model driven by both standard productivity and financial shocks is able to deliver most of the stylized cyclical facts about real and financial variables simultaneously. Second, financial shocks to banking sector are important not only for explaining the dynamics of financial variables but also for the dynamics of standard macroeconomic variables. In particular, the model simulations show that the benchmark model driven by both shocks has better predictions about investment, hours and output than the frictionless version of the model (which is standard RBC model with capital adjustment costs) and than the model driven only by productivity shocks. The benchmark model also performs better than the model with only productivity shocks in terms of its predictions about aggregate financial variables. ${ }^{8}$ Third, the tightness of bank capital constraint given by the Lagrange multiplier in the theoretical model (which determines the banks' ability to extend credit to non-financial firms) tracks the index of tightening credit standards (which shows the adverse changes in banks' lending) constructed by the Federal Reserve Board quite well. This result may also imply that the Lagrange multipliers attached to the financial constraints in DSGE models with credit frictions might contain valuable real-time information about the financial conditions of an economy.

The economic intuition for why financial shocks matter a lot for real fluctuations in the model lies in the effect of these shocks on the tightness of bank capital constraint and credit spread. When financial shocks move the economy around the steady state, they lead to large fluctuations in the tightness of bank capital constraint as evidenced by the big swings in the Lagrange multiplier of the constraint. Since credit spread is a function of this Lagrange multiplier, fluctuations in the latter translate into variations in the former. Credit spread appears as a positive wedge in the intertemporal Euler equation, which determines how households' deposits (savings in the economy) are transformed into bank credit to non-financial firms. Fluctuations in this wedge move the amount of deposits, therefore the amount of bank credit that can be extended to firms. Since productive firms finance their capital expenditures via bank credit, movements in the latter translate into the fluctuations in capital stock. Because hours worked is complementary to capital stock in a standard Cobb-Douglas production function, empirically-

\footnotetext{
${ }^{8}$ The RBC model with capital adjustment costs has no predictions about financial variables since balance sheets of banks in that model are indeterminate.
} 
relevant fluctuations in capital stock lead to empirically-observed fluctuations in hours, which eventually generate observed fluctuations in output.

\section{Related Literature}

This study contributes to recently growing empirical and theoretical literature studying the role of financial sector on business cycle fluctuations. On the empirical side, Adrian and Shin $(2008,2009)$ provide evidence on the time series behavior of balance sheet items of some financial intermediaries using the Flow of Funds data. ${ }^{9}$ However, they do not present standard business cycle statistics of financial flows. ${ }^{10}$ On the theoretical side, the current work differs from the existing literature on financial accelerator effects on demand for credit, arising from the movements in the strength of borrowers' balance sheets. ${ }^{11} \mathrm{I}$ focus on fluctuations in supply of credit driven by movements in the strength of lenders' balance sheets. Meh and Moran (2010) investigate the role of bank capital in transmission of technology, bank capital and monetary policy shocks in a medium-scale New Keynesian, double moral hazard framework. Jermann and Quadrini (2012) study the importance of credit shocks in non-financial sector in explaining the cyclical properties of equity and debt payouts of U.S. non-financial firms in a model without a banking sector.

An independent study that is closely related and complementary to our work is Iacoviello (2014). In a DSGE framework with households, banks, and entrepreneurs each facing endogenous borrowing constraints, he studies how repayment shocks undermine the flow of funds between savers and borrowers in the recent recession. My work is different from his study in terms of both empirical and theoretical contributions. First, in terms of empirical work, I systemically document the business cycle properties of aggregate financial variables in the U.S. banking sector from 1987 to 2010, which I then use to judge the quantitative performance of the theoretical model, while his work particularly focuses on the 2007-09 recession. Second, in the theoretical model presented below, only the banking sector faces endogenous capital constraints, which gives me the ability to isolate the role of banks in the transmission of financial

\footnotetext{
${ }^{9}$ They argue that to the extent that balance sheet fluctuations affect the supply of credit, they have the potential to explain real fluctuations, and they empirically show that bank equity has a significant forecasting power for GDP growth.

${ }^{10}$ The notion of "procyclical" in their papers is with respect to total assets of financial intermediaries, not with respect to GDP as in the current study. In that sense, this study undertakes a more standard business cycle accounting exercise.

${ }^{11}$ For example, see Kiyotaki and Moore (1997), Carlstrom and Fuerst (1998), Bernanke, Gertler, and Gilchrist (1999)
} 
shocks from the role of household and production sectors. Finally, I employ a different methodology of constructing the series of financial shocks from the data. In terms of normative policy, Angeloni and Faia (2010) examine the role of banks in the interaction between monetary policy and macroprudential regulations in a New Keynesian model with bank runs, while Gertler and Kiyotaki (2010), and Gertler and Karadi (2011) investigate the effects of central bank's credit policy aimed at troubled banks. ${ }^{12}$ Finally, in an open-economy framework, Kollmann (2011) studies how a bank capital constraint affects the international business cycles driven by productivity and loan default shocks in a two-country RBC model with a global bank.

The rest of the paper is structured as follows: In Section 2, I document evidence on the real and financial fluctuations in U.S. data. Section 3 describes the theoretical model very briefly. Interested readers may refer to Appendix A for details. Section 4 presents the model parametrization and calibration together with the quantitative results of the model. Section 5 concludes.

\section{Real and Financial Fluctuations in the U.S. economy}

This section documents some key empirical features of financial cycles in the U.S. economy. Table 1 presents the business cycle properties of aggregate financial variables in U.S. commercial banking sector together with standard macro aggregates for the period 1987-2010. ${ }^{13}$ The correlation coefficients in bold font are the maximum ones in their respective rows, which indicate the lead-lag relationship of variables with output. The aggregate financial variables I consider are U.S. commercial banks' assets (bank credit), liabilities (deposits), net worth, leverage ratio and loan spread. Quarterly seasonally-adjusted financial data are taken from the Federal Reserve Board. Quarterly real data are taken from Federal Reserve Economic Data (FRED) of St. Louis FED. Financial data at the FED Board is nominal. GDP deflator from NIPA accounts is used to deflate the financial time series. ${ }^{14}$

Table 1 gives us the following empirical facts about real and financial variables. Consumption and hours are less volatile than output, while investment is more volatile; and consumption,

\footnotetext{
${ }^{12}$ The latter also features the interbank market.

${ }^{13}$ I focus on the period that begins in 1987 for two reasons. First, U.S. banking sector witnessed a significant transformation starting from 1987 such as deregulation of deposit rates, increases in financial flexibility. Second, it also corresponds to a structural break in the volatility of many standard macro variables, which is so-called Great Moderation.

${ }^{14}$ See the data appendix for a more detailed description.
} 
investment, and hours are all strongly procyclical with respect to output. These are standard business-cycle facts; for example, see King and Rebelo (1999). The novel part is to document the business cycle facts of aggregate financial flows: Bank credit, deposits, and loan spread are less volatile than output, while net worth and leverage ratio are several times more volatile. Bank assets and net worth are procyclical, while deposits, leverage ratio, and loan spread are countercyclical. Finally, all financial variables lead the output fluctuations by one to three quarters. ${ }^{15}$ I will assess the quantitative performance of the model below by its ability to match these cyclical properties of real and financial variables simultaneously.

\section{A Business Cycle Model with Financial Sector}

This section discusses the model very briefly. The model is an otherwise standard real business cycle model with a financial sector. The economy consists of four types of agents: households, financial intermediaries, firms, and capital producers. Financial intermediaries play the key role in the model. ${ }^{16}$ They borrow from households by issuing deposits, combines those funds with their own net worth and extend credit to firms by purchasing their shares. Credit frictions in financial sector are modeled as in Gertler and Karadi (2011). The ability of financial intermediaries to borrow from households is limited due to a moral hazard (costly enforcement) problem, leading to endogenous capital constraints for banks in obtaining funds.

Firms finance their capital expenditures in each period by selling shares to financial intermediaries. Capital producers are incorporated into the model in order to introduce capital adjustment costs in a tractable way.

The main difference from Gertler and Karadi (2011) is introducing net worth shocks in the model environment, which alters the ability of banks in obtaining funds from households and lending to the firms. ${ }^{17}$ Moreover, in order to elucidate the underlying basic mechanism of the model as clearly as possible, I abstract from various real and nominal rigidities considered in

\footnotetext{
${ }^{15}$ I also reproduce Table 1 for the period 1987:Q1-2007:Q1 in order to see whether the empirical results are driven or at least substantially affected by the recent economic events starting at 2007:Q3 or not. The reproduced table is available upon request. The results show that the key stylized facts about real and financial variables described above are robust to the sample period taken although there are some negligible quantitative differences.

${ }^{16}$ Market segmentation assumption ensures that households cannot directly lend to non-financial firms and this makes the financial sector essential for transferring funds from households to firms.

${ }^{17}$ I remove the capital quality shocks incorporated into their model since simulating the model with their capital quality shocks shows that those shocks generate excessive volatility in the balance sheet variables of banking sector, which is not inline with the volatility observed in the data.
} 
Gertler and Karadi (2011) such as habit persistence, variable capacity utilization, monopolistic competition and price stickiness.

Table 2 shows the sequence of events in a given time period in the theoretical model. Readers may also refer to Appendix A for model details and to Appendix $\mathrm{C}$ for the competitive equilibrium conditions of the model.

\section{Quantitative Analysis}

This section studies the quantitative predictions of the model by examining the results of numerical simulations of an economy calibrated to quarterly U.S. data. In order to investigate the dynamics of the model, I compute a first-order approximation to the equilibrium conditions using Dynare. ${ }^{18}$ First, I study the long-run properties of the model economy by looking at how the severity of financial frictions and the tightness of the bank capital constraint affect the steady-state values of real and financial variables. Second, I examine the dynamics of the model by conducting impulse response analysis. Third, I present business cycle properties of real and financial variables from stochastic simulations of the benchmark economy with productivity and financial shocks. ${ }^{19}$ Finally, I study the dynamics of the model in response to actual sequence of shocks and compare the simulated time-series of real and financial variables with the actual time-series of these variables in order to assess the quantitative performance of the model. ${ }^{20}$

\subsection{Functional Forms, Parametrization and Calibration}

The quantitative analysis uses the following functional forms for preferences, production technology and capital adjustment costs: ${ }^{21}$

$$
U(c, 1-L)=\log (c)+v(1-L)
$$

\footnotetext{
${ }^{18} \mathrm{I}$ also conduct a second-order approximation to the equilibrium conditions of the model. The main results of the paper including impulse responses and business cycles statistics remained unchanged.

${ }^{19}$ In order to construct the business cycle properties of the model, I follow the standard procedure in the business cycle literature that I use the HP-filtered series of real and financial variables and log-linearly detrended shock series.

${ }^{20}$ Aside from computing HP-filtered business cycle statistics, I also performed this exercise to assess the quantitative fit of the model in matching the actual fluctuations in the data. In this exercise, I use the log-linearly detrended series of real and financial variables rather than HP-filtered series. This is because it is argued in the literature that HP-filter cannot capture the dynamics of series in the beginning and at the end of sample time period well. The results of this exercise are presented in section 4.5.

${ }^{21}$ I choose the functional form of the capital adjustment cost following Bernanke, Gertler and Gilchrist (1999), Gertler, Gilchrist, and Natalucci (2007) etc.
} 


$$
\begin{gathered}
F(K, H)=K^{\alpha} H^{1-\alpha} \\
\Phi\left(\frac{I}{K}\right)=\frac{I}{K}-\frac{\varphi}{2}\left[\frac{I}{K}-\delta\right]^{2}
\end{gathered}
$$

Table 3 lists the parameter values for the model economy. The preference and production parameters are standard in business cycle literature. I take the quarterly discount factor, $\beta$ as 0.9942 to match the $2.37 \%$ average annualized real deposit rate in the U.S. I pick the relative utility weight of labor $v$ as 1.72 to fix hours worked in steady state, $\bar{L}$, at one third of the available time. The share of capital in the production function is set to 0.36 to match the labor share of income in the U.S. data. The capital adjustment cost parameter is taken so as to match the relative volatility of price of investment goods with respect to output in the U.S. data. $^{22}$ The quarterly depreciation rate of capital is set to $2.25 \%$ to match the average annual investment to capital ratio.

The non-standard parameters in our model are the financial sector parameters: the fraction of the revenues that can be diverted, $\lambda$, the proportional transfer to newly entering bankers, $\epsilon$, and the survival probability of bankers, $\theta$. I set $\epsilon$ to 0.001 so that the proportional transfer to newly entering bankers is $0.1 \%$ of aggregate net worth. ${ }^{23}$ I pick other two parameters simultaneously to match the following two targets: an average interest rate spread of 46 basis points, which is the historical average of the difference between the quarterly commercial and industrial loan spread and the quarterly deposit rate from 1987.Q1 to 2010.Q4, and an average leverage ratio of 4.61, which is the historical average of U.S. commercial banks' leverage ratio for the same period. ${ }^{24}$ The resulting values for $\bar{\lambda}$ and $\theta$ are 0.155 and 0.968 , respectively.

Finally, turning to the shock processes, I follow the standard Solow residuals approach to

\footnotetext{
${ }^{22}$ The volatility of price of investment goods is taken from Gomme et al. (2011).

${ }^{23}$ I keep the proportional transfer to newly entering bankers small, so that it does not have significant impact on the results.

${ }^{24}$ There might be different calibration targets for the credit spread in the model depending on its interpretation: loan spread vs. equity return. Here we follow the vast literature on financial accelerator models and choose the former interpretation.
} 
construct the series for productivity shocks. ${ }^{25}$ Using the production function, I obtain

$$
z_{t}=\frac{y_{t}}{K_{t}^{\alpha} H_{t}^{1-\alpha}}
$$

Using the empirical series for output, $y_{t}$, capital, $K_{t}$, and labor, $H_{t}$, I use equation (4) to obtain the $z_{t}$ series. Then I construct the log-deviation of TFP series by linearly detrending the log of the $z_{t}$ series over the period 1987.Q1-2010.Q4.

Similar to the construction of productivity shocks, $\omega_{t}$ series are constructed from the law of motion for bank net worth, which is given by

$$
\omega_{t}=\frac{1}{\theta\left[\left(r_{k t}-r_{t}\right) \frac{\eta_{t-1}}{\lambda-\nu_{t-1}}+\left(1+r_{t}\right)\right]+\epsilon} \frac{n_{t}}{n_{t-1}}
$$

Using the empirical series for net worth, $n_{t}$, credit spread, $r_{k t}-r_{t}$, leverage, $\frac{\eta_{t}}{\lambda-\nu_{t}}$, and gross deposit rate $1+r_{t}$, I use equation (5) obtain the $\omega_{t}$ series. Then I construct the log-deviation of $\omega_{t}$ series by linearly detrending the log of these series over the period 1987.Q1-2010.Q4. The innovations to $\omega_{t}$ are net worth shocks.

After constructing the $z_{t}$ and $\omega_{t}$ series over the period 1987.Q1-2010.Q4, I estimate two independent $\mathrm{AR}(1)$ processes for both series: ${ }^{26}$

$$
\begin{aligned}
& \log \left(z_{t+1}\right)=\rho_{z} \log \left(z_{t}\right)+\epsilon_{t+1}^{z} \\
& \log \left(\omega_{t+1}\right)=\rho_{\omega} \log \left(\omega_{t}\right)+\epsilon_{t+1}^{\omega}
\end{aligned}
$$

where $\epsilon_{z, t+1}$ and $\epsilon_{\omega, t+1}$ are i.i.d. with standard deviations $\sigma_{z}$ and $\sigma_{\omega}$, respectively. The resulting parameters are $\rho_{z}=0.93, \rho_{\omega}=0.37, \sigma_{z}=0.0064$, and $\sigma_{\omega}=0.05$.

The first two panels of Figure 2 plot the variables $z_{t}$ and $\omega_{t}$ constructed using the procedures described above. The figures show that the levels of productivity and credit conditions fell sharply in the recent recession. The bottom panels plot the innovations $\epsilon_{z, t}$ and $\epsilon_{\omega, t}$. These

\footnotetext{
${ }^{25}$ I also perform model-based simulations of macro-financial shocks using utilization-adjusted TFP series constructed by Fernald (2009) since the conventional TFP series constructed using Solow residuals approach may be misleading due to not adjusting for factor-utilization. The results are available from the author upon request. The main findings of the paper remain unchanged when these TFP series are used.

${ }^{26}$ I also estimate a VAR(1) for both shock series. However, the cross-terms in $\operatorname{VAR}(1)$ are statistically insignificant at $5 \%$ significance level. Even if I use the parameters coming from VAR(1) representation, the results are qualitatively very similar although there are some negligible quantitative differences.
} 
innovations are unexpected changes in the levels of productivity and financial conditions. The plots suggest that the U.S. economy is severely hit by both negative productivity and financial shocks in the Great Recession.

\subsection{Long-Run Equilibrium of the Model}

This section presents the deterministic steady-state properties of the model economy. First, I will formally show how the tightness of bank capital constraint affects output. Imposing the steady-state on the competitive equilibrium conditions of the model economy yields the following analytical expression for output:

$$
y=\left[\frac{\alpha}{\frac{(1-\beta \theta) \mu \lambda}{(1-\theta) \beta(1+\mu)}+\frac{(1-\beta)}{\beta}+\delta}\right]^{\frac{1}{(1-\alpha)}} \bar{L}^{2-\alpha}
$$

where $\mu$ is the Lagrange multiplier of bank capital constraint. Taking the partial derivative of output w.r.t. $\mu$, I obtain

$$
\frac{\partial y}{\partial \mu}=-\frac{\alpha}{(1-\alpha)}\left[\frac{\alpha}{\frac{(1-\beta \theta) \mu \lambda}{(1-\theta) \beta(1+\mu)}+\frac{(1-\beta)}{\beta}+\delta}\right]^{\frac{\alpha}{(1-\alpha)}} \bar{L}^{2-\alpha}\left[\frac{(1-\theta) \beta(1-\beta \theta) \lambda}{[(1-\theta) \beta(1+\mu)]^{2}}\right]^{-2}<0
$$

which unambiguously shows that the output will be lower the larger $\mu$. The reason is simple. As the bank capital constraint gets tighter, the credit spread will be larger, as can be seen from the following expression.

$$
\left(r_{k}-r\right)=\frac{(1-\beta \theta) \mu \lambda}{(1-\theta) \beta(1+\mu)}
$$

The term at the right-hand side of equation (57) appears as a positive wedge in the intertemporal Euler equation, which determines how deposits (savings) are transformed into credit to firms in the economy. This positive wedge reduces the amount of savings that can be extended as credit to non-financial firms, lowering their physical capital accumulation, and thus leading to a lower steady-state output. The same mechanism is also at work when shocks move the economy around the steady-state as they tighten or relax the bank capital constraint.

Second, I analytically show how output is affected by the severity of credit frictions in banking sector, which is governed by the fraction of diverted funds by bankers, $\lambda$. Taking the partial derivative of output w.r.t. $\lambda$, I get 
$\frac{\partial y}{\partial \lambda}=-\frac{\alpha \bar{L}^{2-\alpha}}{(1-\alpha)}\left[\frac{\alpha\left[\frac{(1-\beta \theta)[(1-\epsilon) \beta-\theta]}{(1-\theta) \beta(1-\epsilon) \beta}\right]^{\frac{(1-\alpha)}{\alpha}}}{\frac{(1-\beta \theta)[(1-\epsilon) \beta-\theta] \lambda}{(1-\theta) \beta(1-\epsilon) \beta}+\frac{(1-\beta)+\beta \delta}{\beta}}\right]^{\frac{\alpha}{(1-\alpha)}} \quad\left[\frac{(1-\beta \theta)[(1-\epsilon) \beta-\theta] \lambda}{(1-\theta) \beta(1-\epsilon) \beta}+\frac{(1-\beta)+\beta \delta}{\beta}\right]^{-2}<0$

which implies that the steady-state output will be lower the higher the intensity of financial frictions in banking sector. In order to get the intuition behind this result, I display long-run equilibria of real and financial variables as a function of the intensity of the credit friction in the financial sector given by fraction of diverted funds by bankers, $\lambda$. All other parameter values are set to those shown in Table 3. Figure 3 shows that the long-run dynamics of the model economy to changes in $\lambda$ is monotonic and non-linear. As $\lambda$ increases, households' incentive to make deposits into banks falls since the bankers' gain from diverting funds rises. Banks have to finance their equity investment by internal financing rather than external financing. Thus, deposits go down and net worth rises, leading to a fall in banks' leverage ratio. The decline in leverage ratio is sharper than the rise in net worth, inducing a drop in total credit to nonfinancial firms. Credit conditions tighten for firms and their cost of funds given by credit spread goes up. This leads to a reduction in investment and output falls.

\subsection{Intermediary Capital and the Transmission of Shocks}

I present the dynamics of the model in response to productivity and net worth shocks. In the figures below, credit spread, return to capital, and deposit rate are expressed in percentage points per annum. The responses of all other variables are expressed in percentage deviations from their respective steady state values.

Figure 4 presents the impulse responses to a one-time, one-standard deviation negative shock to TFP. The negative technology shock reduces the price of investment goods produced by capital producers by $0.3 \%$ on impact, lowering the value of firms' shares. This makes purchase of their shares less profitable for banks, which can also be observed from the $1.2 \%$ fall in the return to capital. Thus, banks have difficulty in obtaining deposits from households since their equity investment becomes less attractive. This reduces the return to deposits by $0.2 \%$, inducing a countercyclical credit spread. The spread rises by $0.3 \%$ on impact. In order to compensate the fall in their external financing, banks need to finance a larger share of their purchases of equities from their net worth. However, bank net worth also falls by $4 \%$ due to lower asset prices. Since 
the decline in net worth is sharper than the fall in deposits on impact, banks' leverage ratio rises. Hence, the model with productivity shocks generates a countercyclical leverage ratio. Because banks cannot adjust their net worth immediately and the lower price of capital reduces the value of their net worth, their financing conditions tighten and bank lending in the form of equity purchases falls dramatically (by about $4.6 \%$ ), inducing aggregate investment to shrink by $0.9 \%$. Finally, hours fall by $0.15 \%$, and output declines by $1.2 \%$.

Figure 5 presents the impulse responses to a one-time, one-standard deviation negative shock to net worth. The negative net worth shock immediately reduces net worth of banks. Bank net worth falls roughly by $15 \%$ on impact. ${ }^{27}$ In order to compensate the decline in their internal financing, they need to finance a larger share of their purchases of equities from deposits. This induces a rise in their leverage ratio. Hence, the model driven by net worth shocks also generates a countercyclical leverage ratio. Although they have to finance a greater fraction of their equity investment from deposits, their ability to do so is impaired by the fall in their net worth, leading deposits to decline after five quarters. Moreover, the fall in their net worth translates into a reduction in bank credit to firms. Bank credit shrinks by roughly $8 \%$ on impact. ${ }^{28}$ Since firms finance their capital expenditures via bank credit, they cut back their investment severely (by about $2 \%$ ). The drop in investment reduces the price of capital by $0.4 \%$, which lowers banks' net worth further. Hours fall by $0.4 \%$ and output drops by $0.9 \%$ on impact. Finally, consumption rises on impact after the shock hits, which is what was observed at the beginning of the recent financial crisis. ${ }^{29}$

\subsection{Variance Decomposition}

Table 4 reports the variance decomposition of key model variables. The table indicates that financial shocks explain $25 \%$ of the variation in output even though productivity shocks have a first-order effect on output. These shocks also explain $71 \%$ of the fluctuations in investment as they are amplified via the financial accelerator mechanism and have a significant effect on the tightness of bank capital constraint. The variation in hours are also mostly explained by

\footnotetext{
${ }^{27}$ Aggregate net worth of U.S. commercial banks fell by $7.5 \%$ in the first two quarters of the Great Recession.

${ }^{28}$ Aggregate bank credit of U.S. commercial banks decline by nearly $4 \%$ in the first three quarters of the Great Recession.

${ }^{29}$ Barro and King (1984) argue that any shock that reduces the quantity of hours worked on impact has to lead a fall in consumption due to consumption-leisure optimality condition. Ajello (2010) shows that sticky wages are the key factor in generating a positive comovement between consumption and investment after a financial shock.
} 
financial shocks. Since productive firms finance their capital expenditures via bank credit, movements in the latter translate into the fluctuations in capital stock. Because hours worked is complementary to capital stock in a standard Cobb-Douglas production function, strong fluctuations in capital stock caused by these shocks lead to strong fluctuations in hours.

The second part of Table 4 shows that financial shocks derive much of the variation in net worth, leverage ratio, and credit spreads (more than 95\%) as expected. They generate half of the fluctuations in bank credit and deposits. This might due to the fact that productivity shocks have a first-order impact on return to capital as they shift the demand for capital and change its price, affecting the volume of bank credit. Moreover, productivity shocks have a more direct effect on deposit rates and hence the saving motive of households since household income is primarily affected from productivity shocks through wages and interest income.

\subsection{Business Cycle Dynamics}

This section presents numerical results from stochastic simulations of the benchmark economy with productivity and net worth shocks. First, I simulate the model economy 1000 times for 1096 periods each and discard the first 1000 periods in each simulation so that each simulation has the same length as the data sample. I then compute the standard business cycle statistics using the cyclical components of the HP-filtered series. I also conduct the same quantitative exercise for the frictionless version of the benchmark economy, which is essentially the standard RBC model with capital adjustment costs, in order to compare the real fluctuations in both models. Finally, I simulate the model economy only driven by productivity shocks to see the contribution of net worth shocks to the observed dynamics of real and financial variables.

Table 4 presents quarterly real and financial statistics in the data and in the model economies. In particular, it displays the relative standard deviations of real and financial variables with respect to output and their cross-correlations with output. Column 3 of the table shows that the standard RBC model with capital adjustment costs driven by standard productivity shocks is able produce the key business cycle facts in the U.S. data as expected: consumption and hours less volatile than output, while investment is more volatile, all real variables are highly procyclical. However, this model can only explain $80 \%$ of the fluctuations in output and less than half of the relative volatility in hours. It also generates roughly perfect positive correlation between real variables and output, contrary to the data. Moreover, this model has no predictions about financial variables. 
Column 4 of the table shows the business cycle statistics of our model economy with only productivity shocks. This model is much closer to the data in terms of real fluctuations, compared to the RBC model. It now accounts for $85 \%$ of the fluctuations in output and roughly half of the relative volatility in hours. The model is also able to replicate most of the stylized facts about financial variables: bank assets, deposits and loan spread is less volatile than output, while net worth and leverage ratio are more volatile; bank assets and net worth are procyclical, while leverage ratio and loan spread are countercyclical. However, it generates procyclical deposits, contrary to the data. Although the model does a good job in terms of key facts of financial variables, it predicts lower fluctuations. For example, it can explain less than half of the relative volatility in bank assets, roughly half of the relative volatility in deposits, less than one third of the relative volatility in net worth and leverage ratio. The model virtually matches the relative volatility of credit spread. Column 5 of the table shows the real and financial statistics in the benchmark economy driven by both shocks. This model is even closer to the data than the previous model in terms of business cycle properties of real variables. It predicts all of the fluctuations in output, almost all of the relative volatility in hours. The cross correlations of investment and hours with output are quite inline with the data. However, the model generates acyclical consumption. This model has better predictions about financial variables. It is able to reproduce the key facts about aggregate financial variables. Moreover, it now explains more than half of the relative volatility in bank assets, and somewhat overpredicts the relative volatility in other financial variables. The last column of Table 4 establishes the first main result of the paper: the benchmark model driven by both shocks is able to deliver most of the key stylized facts about real and financial variables simultaneously.

\subsection{Model-Based Simulations of Macro-Financial Shocks vs. the U.S. Data}

I also study the dynamics of the model in response to the actual sequence of shocks to see whether the model is able to generate the real and financial cycles observed in the U.S. data. ${ }^{30}$ I basically feed the actual innovations to $z_{t}$ and $\omega_{t}$ into the model and compute the responses of real and financial variables over the period 1987 to 2010.

Figure 5 displays the quarterly time series of output, investment and hours in the data, in

\footnotetext{
${ }^{30}$ Although I feed the actual series of shocks into the model, they are not perfectly anticipated by the agents in the economy as they predict future values of $z_{t}$ and $\omega_{t}$ using the $\operatorname{AR}(1)$ processes given by (6) and (7).
} 
the standard RBC model with capital adjustment costs, and in the benchmark economy. The $\mathrm{RBC}$ model is driven by standard productivity shocks, while the benchmark model is driven by both shocks. Both the quarterly times series of the variables and their model counterparts are log-linearly detrended over the period 1987.Q1 - 2010.Q4, and plotted in percentage deviations from their trends. The correlations between the actual and the model-simulated series are also reported in the graphs. The figure suggests that both the RBC model and the benchmark economy generate series of real variables that closely follow their empirical counterparts. However, the RBC model predicts lower fluctuations in all real variables. In particular, the RBC model predicts a smaller decline in output in the 1990-91 recession. Moreover, it generates declines in investment and hours that are smaller than the actual declines in the 1990-91 and 2007-09 recessions. On the other hand, the benchmark model generates larger fluctuations in real variables, consistent with the data. Since this model has one additional shock compared to the RBC model, higher volatility can be expected. However, the benchmark model also improves upon the RBC model in the sense that for all real variables, the cross-correlations between the data and the benchmark model is much higher than those between the data and the RBC model. Moreover, the model's success in generating empirically-relevant fluctuations in hours hinges on the fact that it is able to produce quantitatively reasonable fluctuations in capital. Since labor is complementary to capital stock in a standard Cobb-Douglas production function, empirically-relevant changes in capital stock lead to observed fluctuations in hours.

Figure 6 displays the quarterly time series of output, investment and hours in the data, in the model driven only by productivity shocks, and in the benchmark economy. The figure suggests that the benchmark economy performs better than the model with only productivity shocks in terms of both volatilities of real variables and cross-correlations of those variables with the data. For all the real variables, the cross-correlations with the data in the benchmark model is higher than those with the data in the model with only productivity shocks.

Figure 7 displays the quarterly time series of output, investment and hours in the data, in the RBC model, and in the model driven only by productivity shocks. This figure suggests that the model with only productivity shocks is not very different from the RBC model in terms of its quantitative performance in real variables. Actually, the series of real variables generated by these two models are almost the same. Therefore, we can say that credit frictions in banking sector by themselves are not enough to improve upon the RBC model and to produce real 
fluctuations consistent with the data. Financial shocks are quite important in explaining the observed dynamics of real variables.

Figure 8 shows the quarterly time series of bank credit, deposits, net worth, leverage ratio, and credit spread both in the data, in the model driven only by productivity shocks and in the benchmark model. Both the quarterly time series of financial variables and their model counterparts are log-linearly detrended over the period 1987.Q1 - 2010.Q4, and plotted in percentage deviations from their trends. Credit spread is plotted in annualized percentages. The correlations between the actual and the model-simulated series are also reported in the graphs. For all the financial variables, the cross-correlations with the data in the benchmark model is significantly higher than those with the data in the model with only productivity shocks. Specifically, for net worth, leverage ratio and credit spread, the benchmark model produces highly positively correlated series with the data, while the model with only productivity shocks predicts negative correlations. Thus, this figure suggests that financial shocks contribute significantly to explaining the observed dynamics of financial variables.

I also conduct the same exercise for the real and financial variables by dropping the 2007-09 financial crisis period since it might be argued that a large part of the improvement generated by the financial friction and the net worth shock may be due to the financial crisis part of the sample. The results are available upon request. In order to save space, I don't report the results here. The findings show that the cross-correlations between the data series and the model-simulated series are still high keeping the main results unchanged although they fell a bit compared to the ones in full sample.

\subsection{Tightness of Credit Conditions in the U.S. Economy}

This section compares the model-construct tightness measure of credit conditions with the actual tightness of credit conditions in the U.S. economy. Figure 9 plots the fluctuations in the Lagrange multiplier of bank capital constraint in the benchmark model and those in the index of credit tightness constructed by Federal Reserve Board using the Senior Loan Officer Opinion Survey on Bank Lending Practices. Starting with the second quarter of 1990, this survey basically asks senior loan officers whether they have recently tighten the credit standards for commercial and industrial loans, and the collected responses are used to create an index of credit tightness as the percentage of respondents, reporting tightening standards. Increases in both the multiplier and the index show the adverse changes in bank lending to non-financial 
businesses. The figure shows that the multiplier tracks the index well. The multiplier also explains the severity of credit conditions experienced by the U.S. economy in the last three recessions by capturing almost most of the fluctuations in the index. Even though there seems to be a modest phase shift between these two series, the figure establishes the third main result of the paper: The fluctuations in the model-construct tightness measure of credit conditions virtually matches those in the index from the survey, implying that U.S. banks experienced a significant deterioration in their lending ability in the last recessions, especially in 1990-91 and 2007-09 recessions. ${ }^{31}$ This result also indicates that the Lagrange multipliers attached to the financial constraints in DSGE models with credit frictions might contain valuable real-time information about the state of the financial side of an economy.

\subsection{The 2007-09 Global Financial Crisis}

Figure 10 displays how some of the real and financial variables fluctuate around the 200709 recession in the data, in the model with only productivity shocks and in the benchmark model. This figure shows the contribution of financial shocks to explaining the movements in some macroeconomic and financial variables such as GDP, investment, hours, bank credit, net worth and leverage ratio. I also include the correlations into the figure in order to have a quantitative measure to compare the performance of the models in addition to the visual comparison. Focusing on real variables indicates that financial shocks improve the quantitative fit of the model in matching the fluctuations in those variables. For example, the correlation estimate between the GDP data series and the benchmark model-simulated GDP series is 0.99 while that estimate between the GDP data series and the model with only productivity shocks simulated GDP series is 0.88 . The same line of argument also applies to investment and hours. In terms of financial variables, financial shocks significantly contribute to capturing the movements in financial variables. For example, the correlation estimate between the leverage ratio data series and the benchmark model-simulated leverage ratio series is 0.93 while that estimate between the leverage ratio data series and the model with only productivity shocks simulated leverage ratio series is -0.72 . Similar level of improvement in model's quantitative fit can be seen from bank credit and net worth panels of the figure. Therefore, this figure shows extra

\footnotetext{
${ }^{31}$ The phase shift between the two series might be due to the inability of standard RBC models to match the lead-lag relationships of macro variables.
} 
evidence on the relevance of introducing financial shocks in the theoretical model.

\section{Conclusion}

This paper quantitatively investigates the joint role of financial shocks and credit frictions affecting banking sector in driving the real and financial fluctuations in the data. To this end, I first characterize the empirical cyclical behavior of aggregate balance sheet variables of the U.S. banking sector. I then use an otherwise standard real business cycle model with a financial sector, which features an agency problem between banks and their depositors, leading to endogenous borrowing constraints for banks in obtaining funds from households. I incorporate empirically-disciplined shocks to bank net worth (i.e. "financial shocks") which affect the ability of banks to obtain funds from households and to extend credit to non-financial sector. The time series of financial shocks are constructed from the data. The resulting shock series show that credit conditions in the U.S. economy deteriorated significantly in the recent recession.

Several key findings emerge from the quantitative analysis. First, the benchmark model driven by both productivity and financial shocks is able to explain most of the empirical facts about real and financial variables simultaneously. Second, financial shocks to banking sector contribute significantly not only to the observed dynamics of aggregate financial variables but also to the observed dynamics of standard macroeconomic variables. In particular, the benchmark model has better predictions about real and financial variables than the model driven only by productivity shocks. Third, the simulation of the benchmark model points a significant worsening in banks' lending ability in 1990-91 and 2007-09 recessions. The main transmission mechanism of financial shocks is through bank capital channel. In particular, financial shocks are transmitted to the real economy through tightening bank capital constraint, which eventually leads to rising credit spread. Non-financial firms perceive this rise in credit spread as an increase in their cost of borrowing from banks, leading to a decline in their external finance for investment expenditures. Falling aggregate demand caused by lower investment reduces the demand for labor, which brings a drop in hours worked, and hence output.

For further research, one can investigate the normative implications of the model in the light of the recent financial crisis, as U.S. government has assisted many financial firms in order to raise their franchise value, and hence to support real economic activity. In order to start thinking about how different policy tools can be implemented in an environment in which the 
financial sector is crucial for business cycle fluctuations and what the welfare implications of these policies are, it is necessary to establish that the model is capable of matching the observed real and financial fluctuations simultaneously. The model proposed in this paper is successful in this dimension.

\section{Acknowledgments}

I would like to thank S. Borağan Aruoba, Sanjay K. Chugh, Pablo N. D’Erasmo, Anton Korinek, Enrique G. Mendoza, John Shea, and Enes Sunel for very constructive comments and suggestions. I also would like to thank seminar participants at the Board of Governors of the Federal Reserve System, Bank of Canada, Bank of England, Central Bank of the Republic of Turkey, University of Maryland, Uppsala University, New Economic School, Bilkent University, Koc University, Ozyegin University, TOBB-ETU, METU-NCC, Istanbul Technical University, 2013 Borsa Istanbul Finance and Economics Conference, 2011 Annual Meeting of the Society for Economic Dynamics, 2011 International Conference on Computing in Economics and Finance, 2011 Eastern Economic Association Conference, 2010 Midwest Macroeconomics Meetings, 2010 International Conference of Middle East Economic Association, 2010 International Conference on Economic Modeling for helpful comments. I am also grateful to the Federal Reserve Board for their hospitality. All remaining errors are mine. An earlier version of this paper was part of my dissertation at the University of Maryland College Park. The views expressed here are those of the author and do not necessarily reflect the views of the Central Bank of the Republic of Turkey. 


\section{References}

[1] Adrian, Tobias and Hyun Song Shin (2008) Liquidity and Leverage. Journal of Financial Intermediation 19 (3), 418-437.

[2] Adrian, Tobias and Hyun Song Shin (2010) Financial Intermediaries and Monetary Economics. Handbook of Monetary Economics 3, 601-650.

[3] Ajello, Andrea. (2010) Financial Intermediation, Investment Dynamics and Business Cycle Fluctuations. Unpublished manuscript, Northwestern University.

[4] Angeloni, Ignazio and Ester Faia (2013) Capital Regulation and Monetary Policy with Fragile Banks. Journal of Monetary Economics 60 (3), 311-324.

[5] Barro, Robert J. and Robert G. King (1984) Time-Separable Preferences and Intertemporal-Substitution Models of Business Cycles. The Quarterly Journal of Economics, 817-839.

[6] Bernanke, Ben S., Mark Gertler and Simon Gilchrist (1999) The Financial Accelerator in a Quantitative Business Cycle Framework. In Handbook of Macroeconomics, edited by John B. Taylor and Michael Woodford, Vol. 1C. Elsevier.

[7] Boyd, John H. (2007) Financial Intermediation. The New Palgrave Dictionary of Economics Online.

[8] Brunnermeier, Markus K. and Lasse H. Pedersen (2009) Market Liquidity and Funding Liquidity. The Review of Financial Studies 22 (6), 2201-2238.

[9] Carlson, Mark A., Thomas King, Kurt Lewis (2011) Distress in the Financial Sector and Economic Activity. The B.E. Journal of Economic Analysis 83 Policy 11 (1), Article 35.

[10] Carlstrom, Charles T. and Timothy S. Fuerst (1997) Agency Costs, Net Worth, and Business Fluctuations: A Computable General Equilibrium Analysis. American Economic Review 87 (5), 893-910.

[11] Carlstrom, Charles T. and Timothy S. Fuerst (1998) Agency Costs and Business Cycles. Economic Theory 12 (3), 583-597.

[12] Christiano, Lawrence, Martin Eichenbaum and Charles L. Evans (2005) Nominal Rigidities and the Dynamic Effects of a Shock to Monetary Policy. Journal of Political Economy 113 (1), 1-45.

[13] Christiano, Lawrence (2010) Remarks on Unconventional Monetary Policy. IJCB Conference, Bank of Japan.

[14] Chugh, Sanjay, (2014) Firm Risk and Leverage Based Business Cycles. Unpublished manuscript, Boston College.

[15] Covas, Francisco and Wouter Den Haan, (2011) The Cyclical Behavior of Debt and Equity Finance. American Economic Review 101(2), 877-899.

[16] Fernald, John, (2009) A Quarterly, Utilization-Adjusted Series on Total Factor Productivity. Unpublished manuscript, Federal Reserve Bank of San Francisco.

[17] Gertler, Mark, Simon Gilchrist and Fabio M. Natalucci (2007) External Constraints on Monetary Policy and the Financial Accelerator. Journal of Money, Credit, and Banking 39(2-3), 295-330.

[18] Gertler, Mark and Nobuhiro Kiyotaki (2010) Financial Intermediation and Credit Policy in Business Cycle Analysis. Handbook of Monetary Economics 3, 547-599. 
[19] Gertler, Mark and Peter Karadi (2011) A Model of Unconventional Monetary Policy. Journal of Monetary Economics 58(1), 17-34.

[20] Gertler, Mark, Nobuhiro Kiyotaki and Alberto Queralto (2012) Financial Crisis, Bank Risk Exposure and Government Financial Policy. Journal of Monetary Economics 59, Supplement, S17-S34.

[21] Gilchrist, Simon, Vladimir Yankov and Egon Zakrajsek (2009) Credit Market Shocks and Economic Fluctuations: Evidence from Corporate Bond and Stock Markets. Journal of Monetary Economics 56(4), 471-493.

[22] Gilchrist, Simon and Egon Zakrajsek (2011) Monetary Policy and Credit Supply Shocks. IMF Economic Review 59, 195-232.

[23] Gomme, Paul, B. Ravikumar and Peter Rupert (2011) The Return to Capital and the Business Cycle. Review of Economic Dynamics 14, 262-278.

[24] Hancock, Diana, Andrew J. Laing and James A. Wilcox (1995) Bank Capital Shocks: Dynamics Effects on Securities, Loans and Capital. Journal of Banking \& Finance 19 (3-4), 661-677.

[25] Hellmann, Thomas F., Kevin C. Murdock and Joseph E. Stiglitz (2000) Liberalization, Moral Hazard in Banking, and Prudential Regulation: Are Capital Requirements Enough?. American Economic Review 90(1), 147-165.

[26] Holmstrom, Bengt and Jean Tirole (1997) Financial Intermediation, Loanable Funds and the Real Sector. Quarterly Journal of Economics 112, 663-691.

[27] Iacoviello, Matteo (2014) Financial Business Cycles. Unpublished manuscript, Federal Reserve Board.

[28] IMF, (2010) Global Financial Stability Report (April 2010). International Monetary Fund.

[29] Jeanne, Olivier and Anton Korinek (2010) "Managing Credit Booms and Busts: A Pigouvian Taxation Approach." NBER Working Papers 16377

[30] Jermann, Urban and Vincenzo Quadrini (2012) Macroeconomic Effects of Financial Shocks. American Economic Review 102(1), 238-271.

[31] Kiyotaki, Nobuhiro and John Moore (1997) Credit Cycles. Journal of Political Economy 105, 211-248.

[32] Kollmann, Robert, Zeno Enders and Gernot J. Müller (2011) Global Banking and International Business Cycles. European Economic Review 55, 407-426.

[33] Korajczyk, Robert A. and Amnon Levy (2003) Capital Structure Choice: Macroeconomic Conditions and Financial Constraints. Journal of Financial Economics 68, 75-109.

[34] Levin, Andrew T., Fabio M. Natalucci and Egon Zakrajsek (2004) The Magnitude and Cyclical Behavior of Financial Market Frictions. Finance and Discussion Series, Federal Reserve Board of Governors, No.70.

[35] Meh, Cesaire and Kevin Moran (2010) The Role of Bank Capital in the Propagation of Shocks. Journal of Economic Dynamics and Control 34, 555-576.

[36] Mendoza, Enrique G. and Vincenzo Quadrini (2010) Financial Globalization, Financial Crises and Contagion. Journal of Monetary Economics 57, 24-39. 
[37] Schmitt-Grohe, Stephanie and Martin Uribe (2004) Solving Dynamic General Equilibrium Models Using a SecondOrder Approximation to the Policy Function. Journal of Economic Dynamics and Control 28, 755-775.

[38] Smets, Frank and Rafael Wouters (2007) Shocks and Frictions in US Business Cycles: A Bayesian DSGE Approach. American Economic Review 97 (3), 586-606.

[39] Woodford, Micheal and Vasco Curdia (2010) Credit Spreads and Monetary Policy. Journal of Money, Credit and Banking 42, Supplement s1, 3-35. 


\section{Tables and Figures}

Table 1: Business Cycle Properties of Real and Financial Variables, Quarterly U.S. Data, 1987- 2010

\begin{tabular}{|c|c|c|c|c|c|c|c|c|c|c|}
\hline & $\begin{array}{l}\text { Standard } \\
\text { Deviation }\end{array}$ & $x_{t-4}$ & $x_{t-3}$ & $x_{t-2}$ & $x_{t-1}$ & $x_{t}$ & $x_{t+1}$ & $x_{t+2}$ & $x_{t+3}$ & $x_{t+4}$ \\
\hline \multicolumn{11}{|l|}{ Real Variables } \\
\hline Output & 1.80 & 0.15 & 0.39 & 0.66 & 0.87 & 1.00 & 0.87 & 0.66 & 0.39 & 0.15 \\
\hline Consumption & 0.45 & -0.20 & 0.06 & 0.37 & 0.66 & 0.82 & 0.80 & 0.67 & 0.46 & 0.25 \\
\hline Investment & 2.73 & 0.27 & 0.49 & 0.71 & 0.87 & 0.97 & 0.82 & 0.59 & 0.33 & 0.09 \\
\hline Hours & 0.91 & -0.01 & 0.19 & 0.43 & 0.65 & 0.83 & 0.89 & 0.83 & 0.68 & 0.44 \\
\hline \multicolumn{11}{|c|}{ Financial Variables } \\
\hline Bank credit & 0.93 & -0.20 & -0.11 & 0.02 & 0.14 & 0.30 & 0.47 & 0.63 & 0.68 & 0.63 \\
\hline Deposits & 0.69 & -0.02 & -0.08 & -0.18 & -0.30 & -0.39 & -0.42 & -0.34 & -0.22 & -0.07 \\
\hline Net Worth & 5.17 & -0.15 & -0.03 & 0.14 & 0.32 & 0.52 & 0.70 & 0.80 & 0.76 & 0.63 \\
\hline Leverage Ratio & 5.61 & 0.16 & 0.05 & -0.12 & -0.30 & -0.49 & -0.66 & -0.74 & -0.70 & -0.55 \\
\hline Loan Spread & 0.08 & 0.05 & 0.04 & -0.08 & -0.21 & -0.39 & -0.42 & -0.43 & -0.32 & -0.18 \\
\hline
\end{tabular}

$\bar{a}$ Business cycle statistics in the table are based on HP-filtered cyclical components of quarterly empirical time series (smoothing parameter:1600).

$b$ The standard deviation of output is expressed in percent; standard deviations of the remaining variables are normalized by the standard deviation of output $(\operatorname{std}(\mathrm{x}) / \operatorname{std}(\mathrm{GDP}))$.

$c$ The correlation coefficients in bold font are the maximum ones in their respective rows.

$d$ Data sources are provided in Appendix A. 


\section{Table 2: The Sequence of Events in a Given Time Period}

1. Productivity $z_{t}$ is realized.

2. Firms hire labor $H_{t}$ and use capital $K_{t}$ they purchased in period $t-1$, which are used for production, $Y_{t}=z_{t} \mathrm{~F}\left(K_{t}, H_{t}\right)$.

3. Firms make their wage payments $w_{t} H_{t}$ and dividend payments to shareholders (banks) from period t-1.

4. Banks make their interest payments on deposits of households from period t-1 and bankers exit with probability (1- $\theta$ ).

5. Recovery rate $\omega_{t}$ is realized.

6. Households make their consumption and saving decisions and deposit their resources at banks.

7. Firms sell their depreciated capital to capital producers. These agents make investment and produce new capital $K_{t+1}$.

8. Firms issue shares $\left[s_{t}=K_{t+1}\right]$ and sell these shares to banks to finance their capital expenditures.

9. Banks purchase firms' shares and their incentive constraints bind.

10. Firms purchase capital $K_{t+1}$ from capital producers at the price of $q_{t}$ with borrowed funds. 
Table 3: Model Parameterization and Calibration

\begin{tabular}{|c|c|c|c|c|}
\hline$\overline{\overline{\text { Description }}}$ & Parameter & Value & Target & 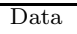 \\
\hline \multicolumn{5}{|l|}{ Preferences } \\
\hline Quarterly discount factor & $\beta$ & 0.9942 & Annualized real deposit rate & $2.37 \%$ \\
\hline Relative utility weight of leisure & $v$ & 1.7167 & Hours worked & 0.3333 \\
\hline \multicolumn{5}{|l|}{ Production Technology } \\
\hline Share of capital in output & $\alpha$ & 0.36 & Labor share of output & 0.64 \\
\hline Capital adjustment cost parameter & $\varphi$ & 3.6 & Relative volatility of price of investment & 0.37 \\
\hline Depreciation rate of capital & $\delta$ & 0.025 & Average annual ratio of investment to capital & $10 \%$ \\
\hline Steady-state total factor productivity & $\bar{z}$ & 1 & Normalization & $\mathrm{N} / \mathrm{A}$ \\
\hline \multicolumn{5}{|l|}{ Financial Intermediaries } \\
\hline Steady-state fraction of assets that can be diverted & $\lambda$ & 0.1548 & Commercial and industrial loan spread & $0.46 \%$ \\
\hline Proportional transfer to the entering bankers & $\epsilon$ & 0.001 & $0.1 \%$ of aggregate net worth & $\mathrm{N} / \mathrm{A}$ \\
\hline Survival probability of the bankers & $\theta$ & 0.9685 & Leverage ratio of commercial banks & 4.62 \\
\hline Steady-state level of net worth shock & $\bar{\omega}$ & 1 & Normalization & $\mathrm{N} / \mathrm{A}$ \\
\hline \multicolumn{5}{|l|}{ Shock Processes } \\
\hline$\overline{\text { Persistence of TFP }}$ process & $\rho_{z}$ & 0.9315 & Quarterly persistence of TFP process & 0.9315 \\
\hline Standard deviation of productivity shock & $\sigma_{z}$ & 0.006424 & Quarterly standard dev. of TFP shock & 0.0064 \\
\hline Persistence of $\omega$ process & $\rho_{\omega}$ & 0.3744 & Quarterly persistence of $\omega$ process & 0.3744 \\
\hline Standard deviation of net worth shock & $\sigma_{\omega}$ & 0.0512 & Quarterly standard dev. of net worth shock & 0.0512 \\
\hline
\end{tabular}


Table 4: Variance Decomposition of Model Variables

\begin{tabular}{lcc}
\hline \hline Variable & TFP Shocks (\%) & Financial Shocks (\%) \\
\hline Real Variables & 75 & 25 \\
Output & 57 & 43 \\
Consumption & 29 & 71 \\
Investment & 17 & 83 \\
Hours & 46 & 54 \\
Financial Variables & 54 & 46 \\
Credit & 5 & 95 \\
Deposits & 2 & 98 \\
Net worth & 3 & 97 \\
Leverage Ratio & & \\
Credit spread & & \\
\hline
\end{tabular}


Table 5: Real and Financial Statistics

\begin{tabular}{|c|c|c|c|c|}
\hline Statistic & Data & $\mathrm{RBC}$ & Only Productivity & Benchmark \\
\hline$\sigma_{Y}$ & 1.80 & 1.44 & 1.53 & 1.81 \\
\hline$\sigma_{C}$ & 0.45 & 0.41 & 0.39 & 0.75 \\
\hline$\sigma_{I}$ & 2.73 & 2.45 & 2.98 & 4.64 \\
\hline$\sigma_{L}$ & 0.91 & 0.40 & 0.46 & 0.84 \\
\hline$\rho_{Y, I}$ & 0.97 & 1.00 & 0.98 & 0.87 \\
\hline$\rho_{Y, C}$ & 0.82 & 0.97 & 0.85 & -0.03 \\
\hline$\rho_{Y, L}$ & 0.83 & 0.99 & 0.96 & 0.81 \\
\hline$\sigma_{\text {Assets }}$ & 0.93 & - & 0.40 & 0.58 \\
\hline$\sigma_{\text {Deposits }}$ & 0.69 & - & 0.39 & 0.87 \\
\hline$\sigma_{N e t W o r t h}$ & 5.17 & - & 1.36 & 5.90 \\
\hline$\sigma_{\text {LeverageR }}$ & 5.61 & - & 1.40 & 6.40 \\
\hline$\sigma_{\text {Spread }}$ & 0.08 & - & 0.07 & 0.23 \\
\hline$\rho_{Y, \text { Assets }}$ & 0.30 & - & 0.90 & 0.88 \\
\hline$\rho_{Y, \text { Deposits }}$ & -0.39 & - & 0.46 & -0.23 \\
\hline$\rho_{Y, N e t W o r t h}$ & 0.52 & - & 0.87 & 0.68 \\
\hline$\rho_{Y, \text { Leverage } R}$ & -0.49 & - & -0.71 & -0.59 \\
\hline$\rho_{Y, \text { Spread }}$ & -0.39 & - & -0.86 & -0.67 \\
\hline
\end{tabular}

a Business cycle statistics in the table are based on HP-filtered cyclical components of quarterly simulated time series (smoothing parameter:1600).

$b$ The standard deviation of output is expressed in percent; standard deviations of the remaining variables are normalized by the standard deviation of output $(\operatorname{std}(\mathrm{x}) / \operatorname{std}(\mathrm{GDP}))$.

${ }^{c}$ In all model economies, capital adjustment cost parameter is set to 3.3 , which is calibrated in benchmark model to match the relative volatility of price of investment. 

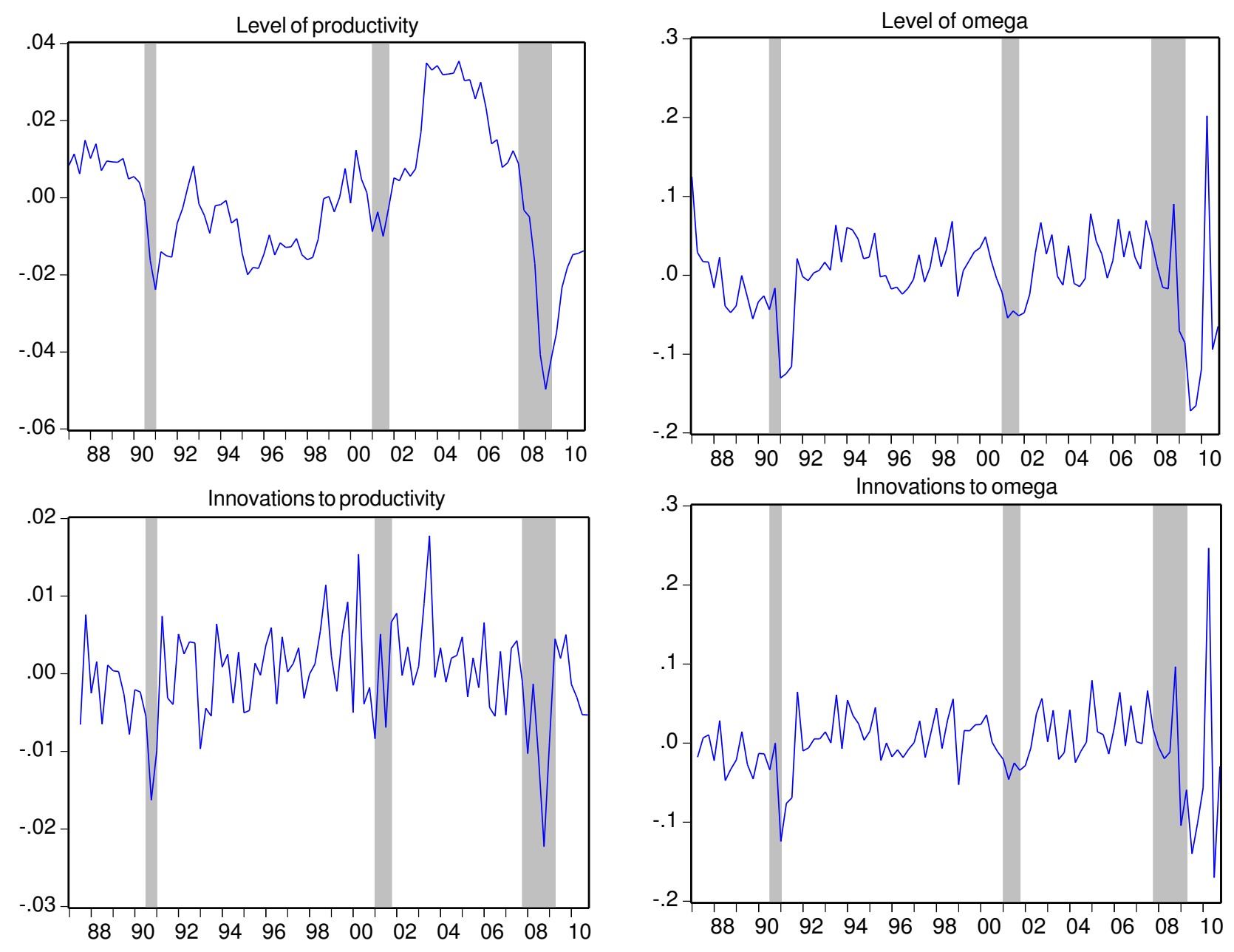

Figure 1: Time Series of Shocks to Productivity and Credit Conditions 

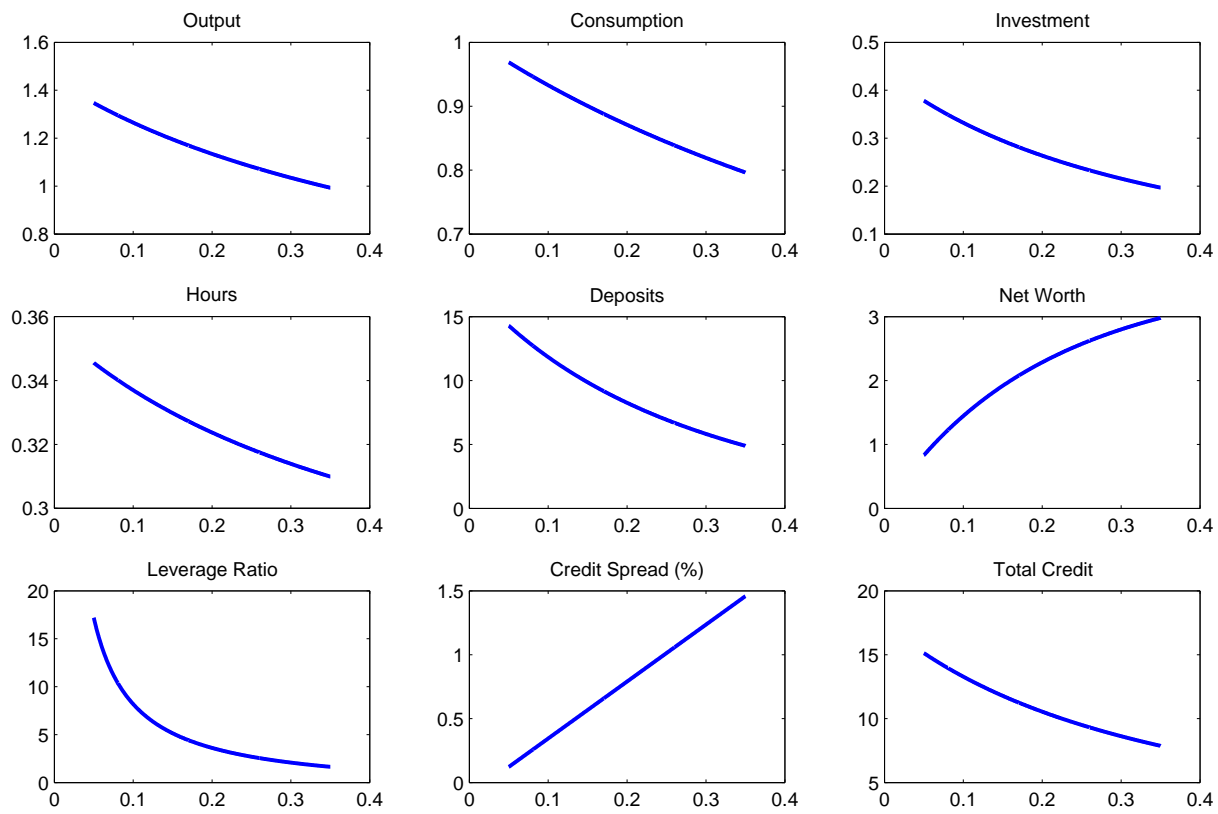

Figure 2: Long-run equilibrium as a function of fraction of diverted funds by bankers 

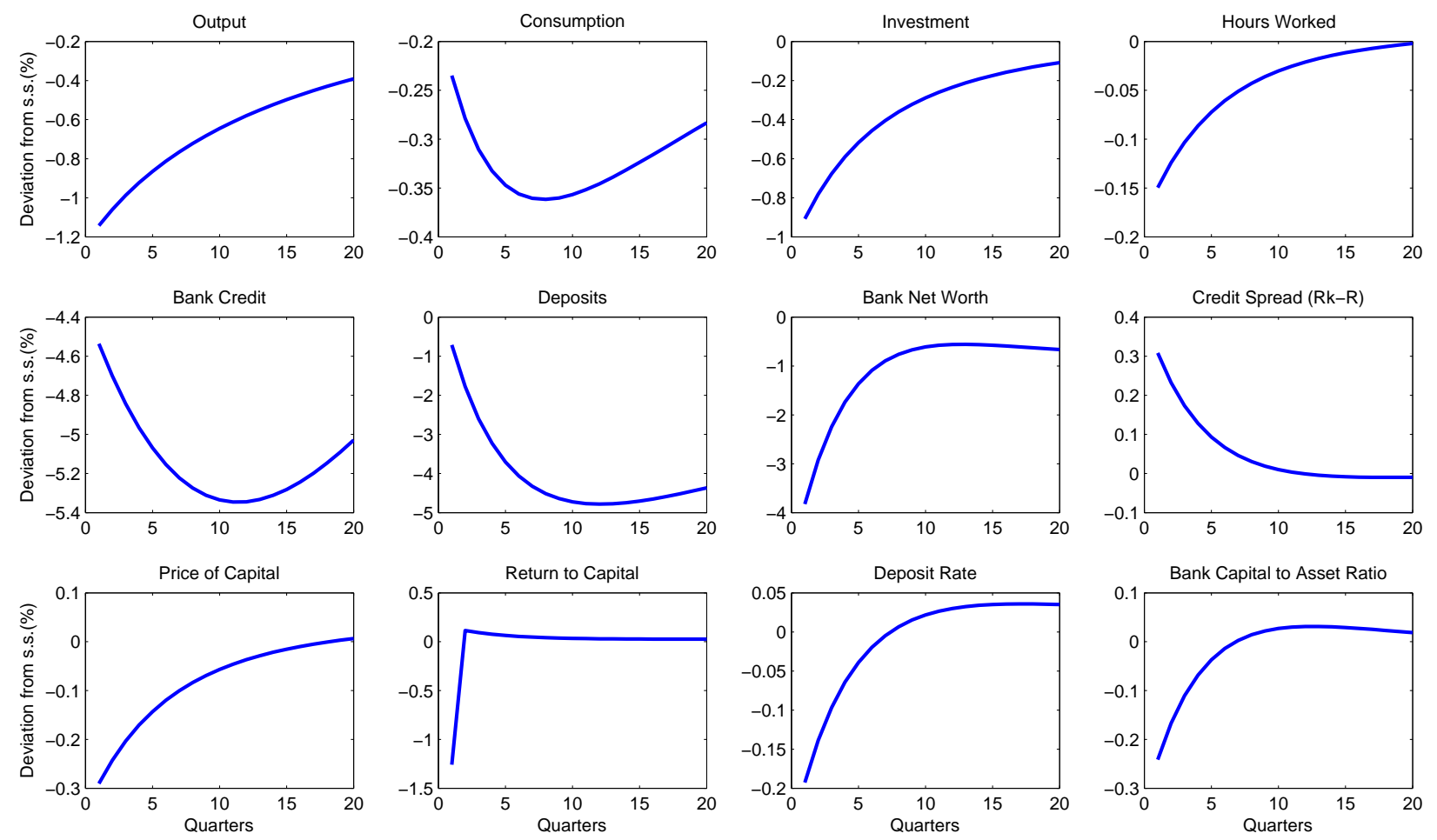

Figure 3: Impulse responses to a negative one-standard-deviation productivity shock 

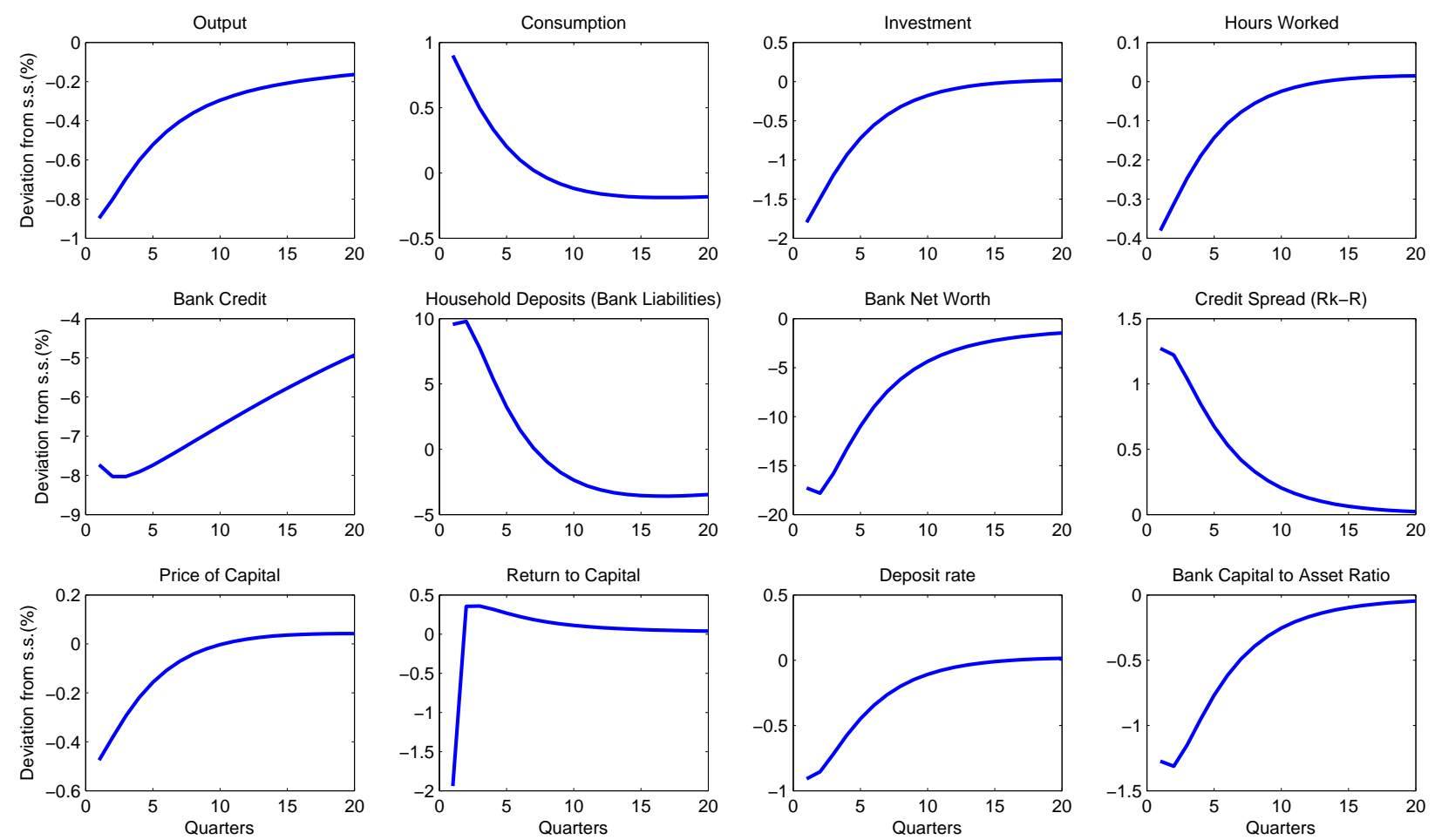

Figure 4: Impulse responses to a negative one-standard-deviation net worth shock 

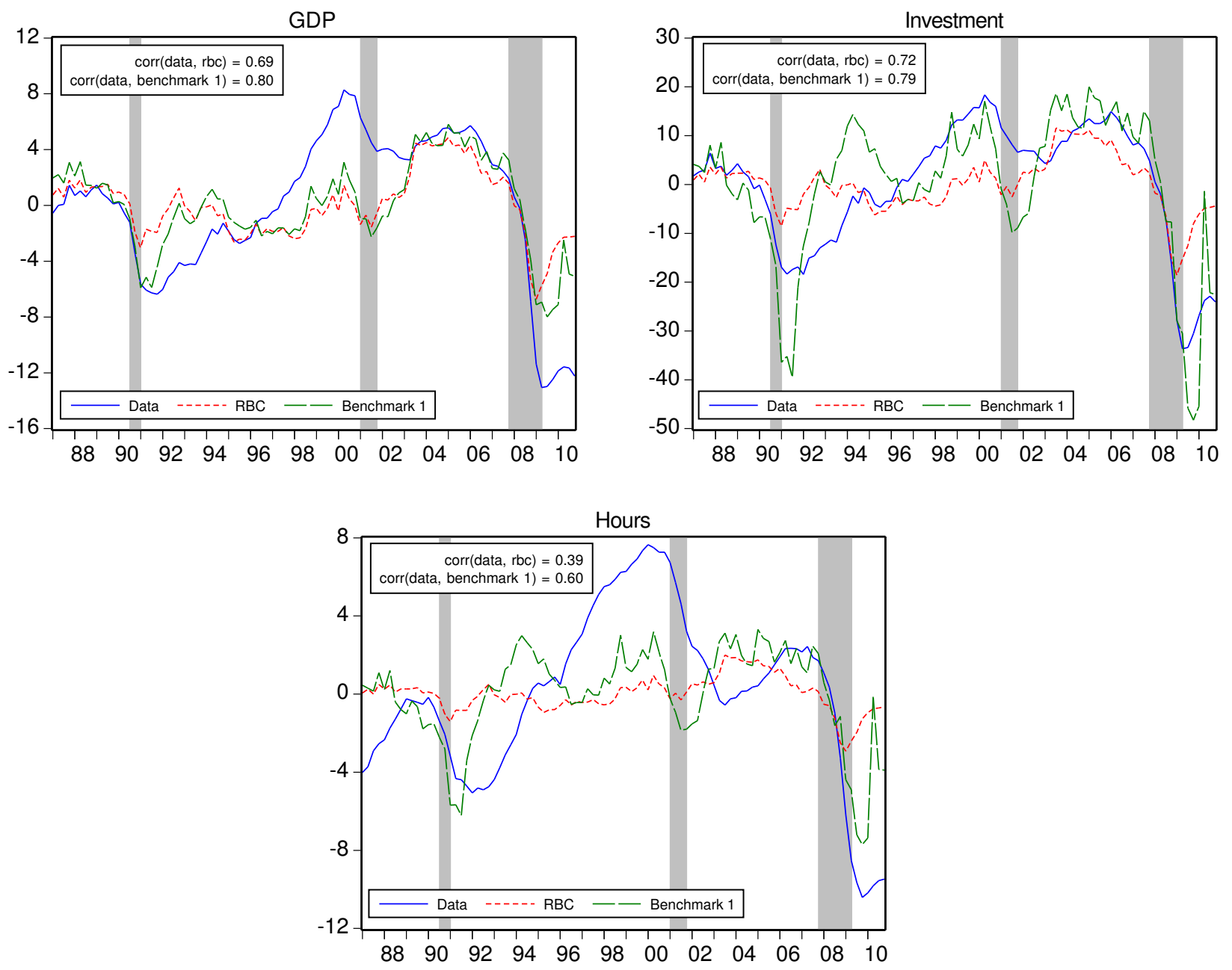

Figure 5: Real Fluctuations: Benchmark vs. RBC model 

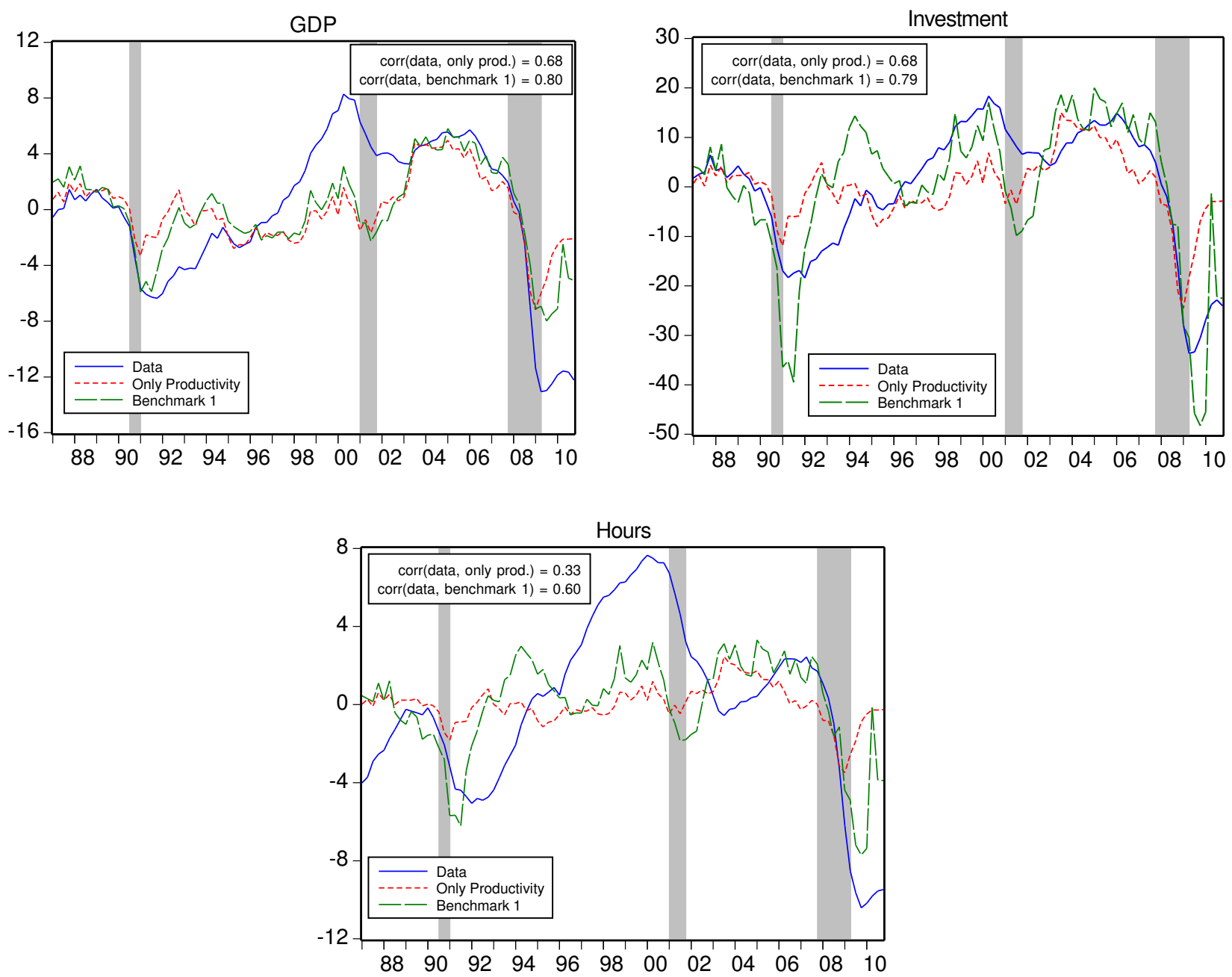

Figure 6: Real Fluctuations: Benchmark vs. Only Productivity 

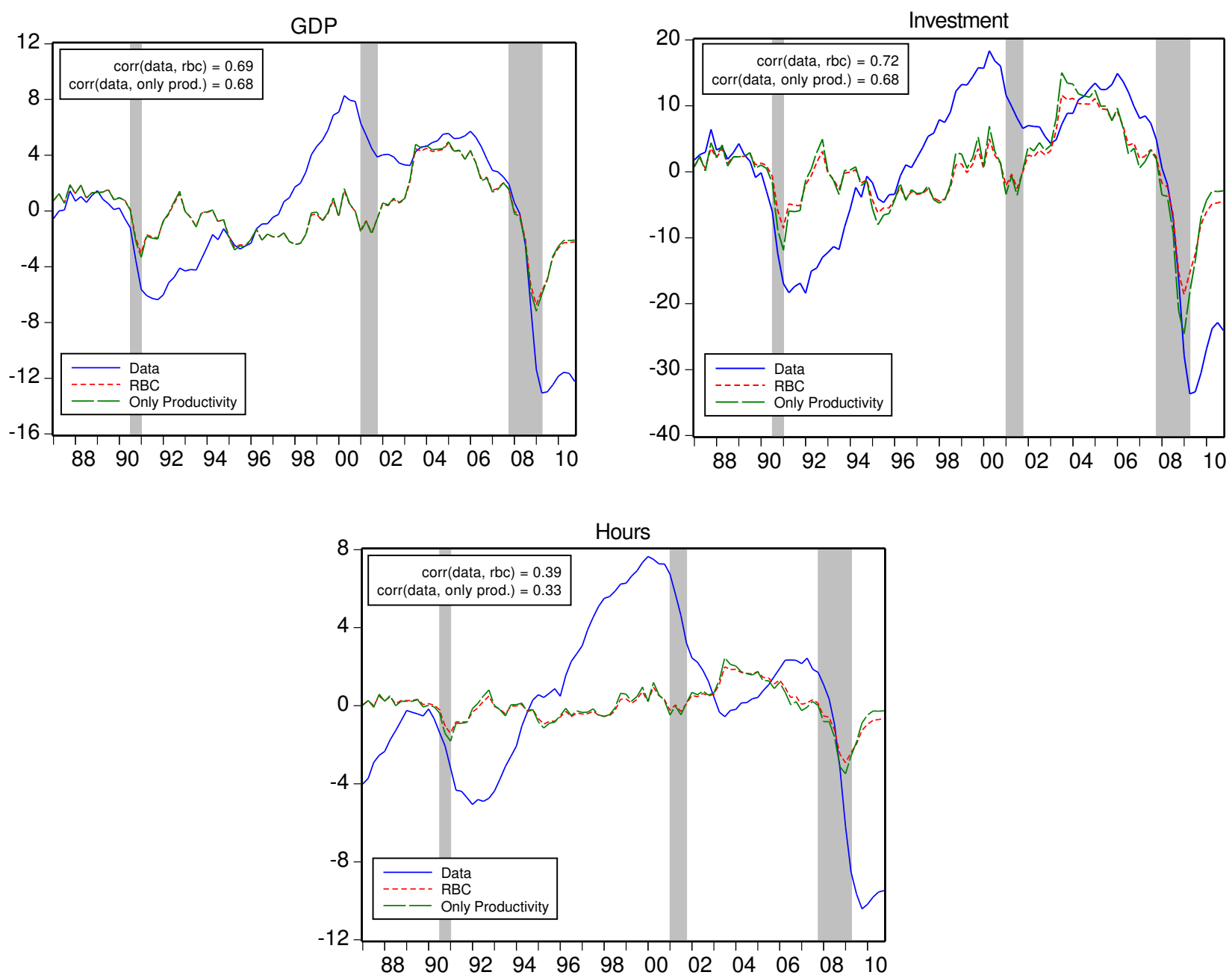

Figure 7: Real Fluctuations: RBC vs. Only Productivity 


\section{Appendix A. The Model}

\section{Appendix A.1. Households}

There is a continuum of identical households of measure unity. Households are infinitely-lived with preferences over consumption $\left(c_{t}\right)$ and leisure $\left(1-L_{t}\right)$ given by

$$
E_{0} \sum_{t=0}^{\infty} \beta^{t} U\left(c_{t}, 1-L_{t}\right)
$$

Each household consumes and supplies labor to firms at the market clearing real wage $w_{t}$. In addition, they save by holding deposits at a riskless real return $r_{t}$ at competitive financial intermediaries.

There are two types of members within each household: workers and bankers. Workers supply labor and return the wages they earn to the household while each banker administers a financial intermediary and transfers any earnings back to the household. Hence, the household owns the financial intermediaries that its bankers administer. However, the deposits that the household holds are put in financial intermediaries that it doesn't own. ${ }^{32}$ Moreover, there is perfect consumption insurance within each household.

At any point in time the fraction $1-\zeta$ of the household members are workers and the remaining fraction $\zeta$ are bankers. An individual household member can switch randomly between these two jobs over time. A banker this period remains a banker next period with probability $\theta$, which is independent of the banker's history. Therefore, the average survival time for a banker in any given period is $1 /(1-\theta)$. The bankers are not infinitely-lived in order to make sure that they don't reach a point where they can finance all equity investment from their own net worth. ${ }^{33}$ Hence, every period $(1-\theta) \zeta$ bankers exit and become workers while the same mass of workers randomly become bankers, keeping the relative proportion of workers and bankers constant. Period $t$ bankers learn about survival and exit at the beginning of period $t+1$. Bankers who exit from the financial sector transfer their accumulated earnings to their respective household. Furthermore, the household provides its new bankers with some start-up funds. ${ }^{34}$

The household budget constraint is given by

$$
c_{t}+b_{t+1}=w_{t} L_{t}+\left(1+r_{t}\right) b_{t}+\Pi_{t}
$$

The household's subjective discount factor is $\beta \in(0,1), c_{t}$ denotes the household's consumption, $b_{t+1}$ is the total amount of deposits that the household gives to the financial intermediary, $r_{t}$ is the non-contingent real return on the deposits from $t-1$ to $t, w_{t}$ is the real wage rate, and $\Pi_{t}$ is the profits to the household from owning capital producers and banks net of the transfer that it gives to its new bankers plus (minus) the amount of wealth redistributed from banks (households) to households (banks).

The household chooses $c_{t}, L_{t}$, and $b_{t+1}$ to maximize (A.1) subject to the sequence of flow budget constraints in (A.2). The resulting first order conditions for labor supply and deposit holdings are given by

$$
\begin{gathered}
\frac{U_{l}(t)}{U_{c}(t)}=w_{t} \\
U_{c}(t)=\beta\left(1+r_{t+1}\right) E_{t} U_{c}(t+1)
\end{gathered}
$$

\footnotetext{
${ }^{32}$ This assumption ensures independent decision-making. Depositors are not the owners of the bank, so the banker don't maximize the depositors' utility, but their own expected terminal net worth.

${ }^{33}$ This assumption ensures that the bankers have to borrow from households to finance their equity purchases.

${ }^{34}$ This assumption ensures that banks don't have zero net worth in any period and is similar to the one about the entrepreneurial wage in Carlstrom and Fuerst (1998), and Bernanke, Gertler, and Gilchrist (1999).
} 
The first condition states that the marginal rate of substitution between consumption and leisure is equal to the wage rate. The second condition is the standard consumption-savings Euler equation, which equates the marginal cost of not consuming and saving today to the expected discounted marginal benefit of consuming tomorrow.

\section{Appendix A.2. Financial Intermediaries}

This section presents balance sheets of financial intermediaries, their profit maximization problem and their net worth evolution.

\section{Appendix A.2.1. Balance Sheets}

Financial intermediaries transfer the funds that they obtain from households to firms. They acquire firm shares and finance these assets with household deposits and their own equity. At the beginning of period $t$, a bank has equity at the amount of $n_{j t-1}$. After it completes its financial activities during the period, its net worth equals to $\widetilde{n}_{j t}$. Then an aggregate net worth shock hits banks' balance sheets. Let's denote $\omega_{t}$ as the time-varying recovery rate of loans as a percentage of bank net worth. Innovations to $\omega_{t}$ are shocks to bank net worth. Therefore, $\omega_{t} \widetilde{n}_{j t}$ is the effective net worth of a bank after the shock. For notational convenience, I denote $\omega_{t} \widetilde{n}_{j t}$ by $n_{j t}$. Hence, $n_{j t}$ is the net worth of a bank $j$ at the end of period $t$ after the net worth shock hits. The balance sheet identity of a financial intermediary $j$ is then given by

$$
q_{t} s_{j t}=b_{j t+1}+n_{j t}
$$

where $q_{t}$ is the price of representative firm's shares, $s_{j t}$ is the quantity of these shares owned by bank $j$, and $b_{j t+1}$ is the amount of deposits that intermediary $j$ obtains from the households. ${ }^{35}$ Banks undertake equity investment and firms finance their capital expenditures by issuing shares. Therefore, the financial contract between the intermediary and the firm is an equity contract (or equivalently a state-dependent debt contract).

The households put their deposits into the financial intermediary at time $t$ and obtain the non-contingent real return $r_{t+1}$ at $t+1$. Therefore, $b_{j t+1}$ is the liabilities of the financial intermediary and $n_{j t}$ is its equity or capital. The financial intermediaries receive ex-post state-contingent return, $r_{k t+1}$ for their equity investment. The fact that $r_{k t+1}$ is potentially greater than $r_{t+1}$ creates an incentive for bankers to engage in financial intermediation.

The financial intermediary's net worth at the beginning of period $t+1$ (before the time $t+1$ net worth shock hits) is given by the difference between the earnings on equity investment in firms (assets of financial intermediary) and interest payments on deposits obtained from the households (liabilities of financial intermediary). Thus the law of motion for bank net worth is given by

$$
\widetilde{n}_{j t+1}=\left(1+r_{k t+1}\right) q_{t} s_{j t}-\left(1+r_{t+1}\right) b_{j t+1}
$$

Using the balance sheet of the financial firm given by (A.5), we can re-write (A.6) as follows:

$$
\tilde{n}_{j t+1}=\left(r_{k t+1}-r_{t+1}\right) q_{t} s_{j t}+\left(1+r_{t+1}\right) n_{j t}
$$

The financial intermediary's net worth at time $t+1$ depends on the premium $r_{k t+1}-r_{t+1}$ that it earns on shares purchased as well as the total value of these shares, $q_{t} s_{j t}$.

\footnotetext{
${ }^{35}$ In U.S. financial data, household deposits constitute $70 \%$ of total liabilities of banks. Boyd (2007) also suggests that demand (checking) deposits form a substantial portion of bank liabilities.
} 


\section{Appendix A.2.2. Profit Maximization}

This section describes banks' profit maximization. The financial intermediary $j$ maximizes its expected discounted terminal net worth, $V_{j t}$, by choosing the amount of firm shares, $s_{j t}$, it purchases, given by

$$
\left.V_{j t}=\max _{s_{j t}} E_{t} \sum_{i=0}^{\infty}(1-\theta) \theta^{i} \beta^{i+1} \Lambda_{t, t+1+i}\left[\left(r_{k t+1+i}-r_{t+1+i}\right) q_{t+i} s_{j t+i}\right]+\left(1+r_{t+1+i}\right) n_{j t+i}\right]
$$

Since the risk premium is positive in any period, the financial intermediary will always have an incentive to buy firms' shares. Obtaining additional funds (deposits) from the households is the only way to achieve this. However, the agency problem described below introduces an endogenous borrowing constraint for banks, thus a limit on the size of the financial intermediaries: At the end of the period, the financial intermediary may choose to divert $\lambda$ fraction of available funds from its shares of firms with no legal ramification and give them to the household of which the banker is a member. If the financial intermediary diverts the funds, the assumed legal structure ensures that depositors are able to force the intermediary to go bankrupt and they may recover the remaining fraction $1-\lambda$ of the assets. They are not able to get the remaining fraction $\lambda$ of the funds since, by assumption, the cost of recovering these funds is too high. ${ }^{36}$ Therefore, for the banks not to have an incentive to divert the funds, the following incentive compatibility constraint must be satisfied at the end of period $t$ :

$$
V_{j t} \geq \lambda q_{t} s_{j t}
$$

The left-hand side of (A.9) is the value of operating for the bank (or equivalently cost of diverting funds) while the right-hand side is the gain from diverting $\lambda$ fraction of assets. The intuition for this constraint is that in order for the financial intermediary not to divert the funds and for the households to put their deposits into the bank, the value of operating in financial sector must be greater than or equal to the gain from diverting assets.

A financial intermediary's objective is to maximize the expected return to its portfolio consisting of firms' shares and its capital subject to the incentive compatibility constraint. Then its demand for shares is fully determined by its net worth position, since as long as the expected return from the portfolio is strictly positive, it will expand its lending (its size) until the incentive compatibility constraint binds.

\section{Appendix A.2.3. Leverage Ratio and Net Worth Evolution}

Proposition 1 The expected discounted terminal net worth of a bank can be expressed as the sum of expected discounted total return to its equity investment into firms and expected discounted total return to its existing net worth.

Proof: See Appendix B.1

Proposition 1 states that that $V_{j t}$ can be expressed as follows:

$$
V_{j t}=\nu_{t} q_{t} s_{j t}+\eta_{t} n_{j t}
$$

where

\footnotetext{
${ }^{36}$ As Christiano (2010) suggests, diverting funds is meant to say that bankers might not manage funds in the interest of depositors or they might invest funds into risky projects which do not earn a high return for depositors but a high excess return for bankers themselves (Bankers might invest $\lambda$ fraction of funds into very risky projects, which could potentially go bankrupt and reduce equilibrium return to depositors). Taking this into consideration, depositors put their money at banks up to a threshold level beyond which if bankers make risky investments, they do this at their own risk. This threshold level of deposits can be thought as if deposits expand beyond that level, banks would have an incentive to default. The market discipline prevents deposits from expanding beyond the default threshold level and interest rate spreads reflect this fear of default although defaults are not observed in equilibrium.
} 


$$
\begin{gathered}
\nu_{t}=E_{t}\left[(1-\theta) \beta \Lambda_{t, t+1}\left(r_{k t+1}-r_{t+1}\right)+\beta \Lambda_{t, t+1} \theta \frac{q_{t+1} s_{j t+1}}{q_{t} s_{j t}} \nu_{t+1}\right] \\
\eta_{t}=E_{t}\left[(1-\theta) \beta \Lambda_{t, t+1}\left(1+r_{t+1}\right)+\beta \Lambda_{t, t+1} \theta \frac{n_{j t+1}}{n_{j t}} \eta_{t+1}\right]
\end{gathered}
$$

$\nu_{t}$ can be interpreted as the expected discounted marginal gain to the bank of buying one more unit of firms' shares, holding its net worth $n_{j t}$ constant. The first term is the discounted value of the net return on shares to the bank if it exits the financial sector tomorrow. The second term is the continuation value of its increased assets if it survives. Meanwhile, $\eta_{t}$ can be interpreted as the expected discounted marginal benefit of having one more unit of net worth, holding $q_{t} s_{j t}$ constant. The first term is the discounted value of the return on net worth to the bank if it exits the financial sector tomorrow. The second term is the continuation value of its increased net worth if it survives.

Therefore, we can write the incentive compatibility constraint as follows:

$$
\nu_{t} q_{t} s_{j t}+\eta_{t} n_{j t} \geq \lambda q_{t} s_{j t}
$$

The incentive compatibility constraint binds as long as $0<\nu_{t}<\lambda$. The intuition is as follows: Assume that $\nu_{t} \geq \lambda$. Then the left-hand side of (A.13) is always greater than the right-hand side of (A.13) since $\eta_{t} n_{j t}>0$ as can be seen from (A.12). The franchise value of the bank is always higher than the gain from diverting funds. Therefore, the constraint is always slack. Moreover, assume that $\nu_{t} \leq 0$. Since $\nu_{t}$ is the expected discounted marginal gain to the bank of increasing its assets, the intermediary does not have the incentive to expand its assets when $\nu_{t} \leq 0$. In this case, the constraint does not bind because the intermediary does not collect any deposits from households.

The profits of the financial intermediary will be affected by the premium $r_{k t+1}-r_{t+1}$. That is, the banker will not have any incentive to buy firms' shares if the discounted return on these shares is less than the discounted cost of deposits. Thus the financial firm will continue to operate in period $t+i$ if the following inequality is satisfied:

$$
E_{t+i} \beta \Lambda_{t, t+1+i}\left(r_{k t+1+i}-r_{t+1+i}\right) \geq 0 \quad \forall i \geq 0
$$

where $\beta \Lambda_{t, t+1+i}$ is the stochastic discount factor that the financial firm applies to its earnings at $t+1+i$. The moral hazard problem between households and banks described above limits banks' ability to obtain deposits from the households, leading to a positive premium. The following proposition establishes this fact.

Proposition 2 Risk premium is positive as long as the incentive compatibility constraint binds.

Proof: See Appendix B.2

When this constraint binds, the financial intermediary's assets are limited by its net worth. That is, if this constraint binds, the funds that the intermediary can obtain from households will depend positively on its equity capital:

$$
q_{t} s_{j t}=\frac{\eta_{t}}{\lambda-\nu_{t}} n_{j t}
$$

The constraint (A.15) limits the leverage of the financial intermediary to the point where its incentive to divert funds is exactly balanced by its loss from doing so. Thus, the costly enforcement problem leads to an endogenous borrowing constraint on the bank's ability to acquire assets. When bank's leverage ratio and/or bank equity is high, it can extend more credit to non-financial firms. Conversely, de-leveraging or the deterioration in net worth in bad times will limit the bank's ability to extend credit. Note that by manipulating this expression using the balance sheet, I can obtain the bank's leverage ratio as follows:

$$
\frac{b_{j t+1}}{n_{j t}}=\frac{\eta_{t}}{\lambda-\nu_{t}}-1
$$


The leverage ratio increases in the expected marginal benefit of buying one more unit of firm share, and in the expected marginal gain of having one more unit of net worth. Intuitively, increases in $\eta_{t}$ or $\nu_{t}$ mean that financial intermediation is expected to be more lucrative going forward, which makes it less attractive to divert funds today and thus increases the amount of funds depositors are willing to entrust to the financial intermediary. ${ }^{37}$

Using (A.15), I can re-write the law of motion for the banker's net worth as follows:

$$
\widetilde{n}_{j t+1}=\left[\left(r_{k t+1}-r_{t+1}\right) \frac{\eta_{t}}{\lambda-\nu_{t}}+\left(1+r_{t+1}\right)\right] n_{j t}
$$

The sensitivity of net worth of the financial intermediary $j$ at $t+1$ to the ex-post realization of the premium $r_{k t+1}-r_{t+1}$ increases in the leverage ratio.

Proposition 3 Banks have an identical leverage ratio as none of its components depends on bank-specific factors.

Proof: From (A.17), one can obtain the following:

$$
\begin{gathered}
\frac{n_{j t+1}}{n_{j t}}=\left[\left(r_{k t+1}-r_{t+1}\right) \frac{\eta_{t}}{\lambda-\nu_{t}}+\left(1+r_{t+1}\right)\right] \\
\frac{q_{t+1} s_{j t+1}}{q_{t} s_{j t}}=\frac{\frac{\eta_{t+1}}{\lambda-\nu_{t+1}}}{\frac{\eta_{t}}{\lambda-\nu_{t}}} \frac{n_{j t+1}}{n_{j t}}
\end{gathered}
$$

The expressions above show that banks have identical expected growth rates of assets and net worth, thus have identical leverage ratios. ${ }^{38}$

By using Proposition 3, we can sum demand for assets across j to obtain the total intermediary demand for assets:

$$
q_{t} s_{t}=\frac{\eta_{t}}{\lambda-\nu_{t}} n_{t}
$$

where $s_{t}$ is the aggregate amount of assets held by financial intermediaries and $n_{t}$ is the aggregate intermediary net worth. In the equilibrium of the model, movements in the leverage ratio of financial firms and/or in their net worth will generate fluctuations in total intermediary assets.

The aggregate intermediary net worth at the beginning of period $t$ (before the net worth shock hits but after exit and entry), $\widetilde{n}_{t}$, is the sum of the net worth of surviving financial intermediaries from the previous period, $\widetilde{n}_{e t}$, and the net worth of entering financial intermediaries, $\widetilde{n}_{n t}$. Thus, we have

$$
\widetilde{n}_{t}=\widetilde{n}_{e t}+\widetilde{n}_{n t}
$$

Since the fraction $\theta$ of the financial intermediaries at time $t-1$ will survive until time $t$, their net worth, $\widetilde{n}_{e t}$, is given by

$$
\widetilde{n}_{e t}=\theta\left[\left(r_{k t}-r_{t}\right) \frac{\eta_{t-1}}{\lambda-\nu_{t-1}}+\left(1+r_{t}\right)\right] n_{t-1}
$$

\footnotetext{
${ }^{37}$ The amount of deposits at banks does directly depend on banks' net worth. In good times banks' net worth is relatively high and depositors believe that bankers do not misbehave in terms of managing their funds properly. In these times, credit spreads can be fully explained by observed bankruptcies and intermediation costs. However, in bad times, banks experience substantial declines in their net worth and depositors are hesitant about putting their money in banks. In these times, the financial sector operates at a less efficient level and a smaller number of investment projects are funded. Large credit spread observed in these times can be explained by the above factors plus the inefficiency in the banking system.

${ }^{38}$ This immediately implies that $\eta_{t}$ and $\nu_{t}$ are independent of $\mathrm{j}$. In Appendix B.1, I use this result in explicit derivation of $\eta_{t}$ and $\nu_{t}$.
} 
Newly entering financial intermediaries receive start-up funds from their respective households. The start-up funds are assumed to be a transfer equal to a fraction of the net worth of exiting bankers. ${ }^{39}$ The total final period net worth of exiting bankers at time $t$ is equal to $(1-\theta) n_{t-1}$. The household is assumed to transfer the fraction $\frac{\epsilon}{(1-\theta)}$ of the total final period net worth to its newly entering financial intermediaries. Therefore, we have

$$
\widetilde{n}_{n t}=\epsilon n_{t-1}
$$

Using (A.21), (A.22), and (A.23), we obtain the following law of motion for $\widetilde{n}_{t}$ :

$$
\widetilde{n}_{t}=\theta\left[\left(r_{k t}-r_{t}\right) \frac{\eta_{t-1}}{\lambda-\nu_{t-1}}+\left(1+r_{t}\right)\right] n_{t-1}+\epsilon n_{t-1}
$$

\section{Appendix A.3. Firms}

There is a continuum of unit mass of firms that produce the final output in the economy. The production technology at time $t$ is described by the constant returns to scale function:

$$
Y_{t}=z_{t} F\left(K_{t}, H_{t}\right)=z_{t} K_{t}^{\alpha} H_{t}^{1-\alpha}
$$

where $K_{t}$ is the firm's capital stock, $H_{t}$ is the firm's hiring of labor and $z_{t}$ is an aggregate TFP realization.

Firms acquire capital $K_{t+1}$ at the end of period $t$ to produce the final output in the next period. After producing at time $t+1$, the firm can sell the capital on the open market.

Firms finance their capital expenditures in each period by issuing equities and selling them to financial intermediaries. Firms issue $s_{t}$ units of state-contingent claims (equity), which is equal to the number of units of capital acquired $K_{t+1}$. The financial contract between a financial intermediary and a firm is an equity contract (or equivalently, a state contingent debt contract). The firm pays a state-contingent interest rate equal to the ex-post return on capital $r_{k t+1}$ to the financial intermediary. The firms set their capital demand $K_{t+1}$ taking this stochastic repayment into consideration. At the beginning of period $t+1$ (after shocks are realized), when output becomes available, firms obtain resources $Y_{t+1}$ and use them to make repayments to shareholders (or financial intermediaries). The firm prices each financial claim at the price of a unit of capital, $q_{t}$. Thus, we have

$$
q_{t} s_{t}=q_{t} K_{t+1}
$$

There are no frictions for firms in obtaining funds from financial intermediaries. The bank has perfect information about the firm and there is perfect enforcement. Therefore, in the current model, only banks face endogenous borrowing constraints in obtaining funds. These constraints directly affect the supply of funds to the firms.

Firms choose the labor demand at time $t$ as follows:

$$
w_{t}=z_{t} F_{H}\left(K_{t}, H_{t}\right)
$$

Then firms pay out the ex-post return to capital to the banks given that they earn zero profit state by state. Therefore, ex-post return to capital is given by

\footnotetext{
${ }^{39}$ This assumption is slightly different from that in Gertler\&Karadi (2011). They assume that the net worth of newly entering bankers is a fraction of banks' total assets rather than its net worth. Since the fraction is small, it does not change the main results of the study significantly.
} 


$$
r_{k t+1}=\frac{z_{t+1} F_{K}\left(K_{t+1}, H_{t+1}\right)+q_{t+1}(1-\delta)}{q_{t}}-1
$$

Labor demand condition (A.27) simply states that the wage rate is equal to the marginal product of labor. Moreover, condition (A.28) states that the ex-post real rate of return on capital is equal to the marginal product of capital plus the capital gain from changed prices.

\section{Appendix A.4. Capital Producers}

Following the literature on financial accelerator, I incorporate capital producers into the model in order to introduce capital adjustment costs in a tractable way. Capital adjustment costs are needed to introduce some variation in the price of capital; otherwise the price of capital will not respond to the changes in capital stock and will always be equal to $1 .{ }^{40}$

I assume that households own capital producers and receive any profits. At the end of period $t$, competitive capital producers buy capital from firms to repair the depreciated capital and to build new capital. Then they sell both the new and repaired capital. The cost of replacing the depreciated capital is unity; thus the price of a unit of new capital or repaired capital is $q_{t}$. The profit maximization problem of the capital producers is given by:

$$
\begin{gathered}
\max _{I_{t}} q_{t} K_{t+1}-q_{t}(1-\delta) K_{t}-I_{t} \\
\text { s.t. } K_{t+1}=(1-\delta) K_{t}+\Phi\left(\frac{I_{t}}{K_{t}}\right) K_{t}
\end{gathered}
$$

where $\left.I_{t}\right)$ is the total investment by capital producing firms and $\Phi\left(\frac{I_{t}}{K_{t}}\right)$ is the capital adjustment cost function. The resulting optimality condition gives the following "Q" relation for investment:

$$
q_{t}=\left[\Phi^{\prime}\left(\frac{I_{t}}{K_{t}}\right)\right]^{-1}
$$

where $\Phi^{\prime}\left(\frac{I_{t}}{K_{t}}\right)$ is the partial derivative of the capital adjustment cost function with respect to investment-capital ratio at time $t$. Equation (A.31) shows that the fluctuations in investment expenditures will create variation in the price of capital. A fall in investment at time $t$ (ceteris paribus) will reduce the price of capital in the same period.

\section{Appendix B. Data Appendix}

Quarterly seasonally-adjusted data on standard macroeconomic variables except Hours are taken from the Federal Reserve Economic Data (FRED) of St. Louis FED. Hours data are taken from Current Employment Statistics survey published by the Bureau of Labor Statistics. GDP deflator from NIPA accounts is used to deflate the time series of the nominal macro aggregates. Consumption is the sum of "Personal consumption expenditures on nondurables" (PCND) and "Personal consumption expenditures on services". Investment is the sum of "Personal consumption expenditures on durables" (PCDG) and "Gross private domestic investment" (GPDI). GDP is the sum of Consumption and Investment. Hours is computed as the multiplication of "average weekly hours in private sector" with "average number of workers in private sector". Quarterly time series of capital stock to obtain $z_{t}$ series are constructed using the approach described in the online appendix of Jermann and Quadrini (2010).

\footnotetext{
${ }^{40}$ There will be no financial accelerator between households and banks if there is no variation in the price of capital.
} 
Quarterly financial time series of Bank assets and Bank liabilities are constructed using the monthly data on Assets and Liabilities of Commercial Banks in the U.S. from Data Download Program of Statistical \& Historical Database of the Federal Reserve Board. Financial data at the FED board are seasonally-adjusted but nominal. GDP deflator from NIPA accounts is used to deflate the financial time series. Bank assets are bank credit at the asset side of the balance sheet of the U.S. commercial banks. Bank liabilities are deposits held at the U.S. commercial banks. Quarterly time series of Loan spread are taken from Survey of Terms of Business Lending from Statistical \& Historical Database of the FED Board. Loan spread is commercial and industrial loan spread over intended federal funds rate. Quarterly deposit rates are constructed using monthly data on 3-month certificate of deposit secondary market rate from FRED. The inflation rate computed from GDP deflator is used to make nominal deposit rate data real.

\section{Appendix C. Proofs of Propositions}

\section{Appendix C.1. Proof of Proposition 1}

Let's conjecture that the bank's franchise value is given by

$$
V_{j t}=\nu_{t} q_{t} s_{j t}+\eta_{t} n_{t}
$$

Comparing the conjectured solution for $V_{j t}$ to the expected discounted terminal net worth yields the following expressions,

$$
\begin{gathered}
\nu_{t} q_{t} s_{j t}=E_{t} \sum_{i=0}^{\infty}(1-\theta) \theta^{i} \beta^{i+1} \Lambda_{t, t+1+i}\left[\left(r_{k t+1+i}-r_{t+1+i}\right) q_{t+i} s_{j t+i}\right] \\
\eta_{t} n_{j t}=E_{t} \sum_{i=0}^{\infty}(1-\theta) \theta^{i} \beta^{i+1} \Lambda_{t, t+1+i}\left(1+r_{t+1+i}\right) n_{j t+i}
\end{gathered}
$$

I write $\nu_{t}$ and $\eta_{t}$ recursively using the expression above. Let's begin with $\nu_{t}$. To ease the notation, let's drop expectations for now.

$$
\nu_{t}=\sum_{i=0}^{\infty}(1-\theta) \theta^{i} \beta^{i+1} \Lambda_{t, t+1+i}\left[\left(r_{k t+1+i}-r_{t+1+i}\right) x_{t, t+i}\right]
$$

where $x_{t, t+i}=\frac{q_{t+i} s_{j t+i}}{q_{t} s_{j t}}$.

$$
\begin{gathered}
\nu_{t}=(1-\theta) \beta \Lambda_{t, t+1}\left(r_{k t+1}-r_{t+1}\right)+\sum_{i=1}^{\infty}(1-\theta) \theta^{i} \beta^{i+1} \Lambda_{t, t+1+i}\left[\left(r_{k t+1+i}-r_{t+1+i}\right) x_{t, t+i}\right] \\
\nu_{t}=(1-\theta) \beta \Lambda_{t, t+1}\left(r_{k t+1}-r_{t+1}\right)+\beta \Lambda_{t, t+1} \theta x_{t, t+1} \sum_{i=0}^{\infty}(1-\theta) \theta^{i+1} \beta^{i+1} \Lambda_{t+1, t+2+i}\left[\left(r_{k t+2+i}-r_{t+2+i}\right) x_{t+1, t+1+i}\right]
\end{gathered}
$$

The infinite sum at the right-hand side of equation (C.6) is one period updated version of equation (C.4), given by

$$
\nu_{t+1}=\sum_{i=0}^{\infty}(1-\theta) \theta^{i+1} \beta^{i+1} \Lambda_{t+1, t+2+i}\left[\left(r_{k t+2+i}-r_{t+2+i}\right) x_{t+1, t+1+i}\right]
$$

where $x_{t+1, t+1+i}=\frac{q_{t+1+i} s_{j t+1+i}}{q_{t+1} s_{j t+1}}$.

Hence, we can re-write (C.6) with the expectations as follows: 


$$
\nu_{t}=E_{t}\left[(1-\theta) \beta \Lambda_{t, t+1}\left(r_{k t+1}-r_{t+1}\right)+\beta \Lambda_{t, t+1} \theta x_{t, t+1} \nu_{t+1}\right]
$$

Let's continue with $\eta_{t}$. To ease the notation, let's drop expectations for now.

$$
\eta_{t}=\sum_{i=0}^{\infty}(1-\theta) \theta^{i} \beta^{i+1} \Lambda_{t, t+1+i}\left(1+r_{t+1+i}\right) z_{t, t+i}
$$

where $z_{t, t+i}=\frac{n_{j t+i}}{n_{j t}}$

$$
\begin{gathered}
\eta_{t}=(1-\theta) \beta \Lambda_{t, t+1}\left(1+r_{t+1}\right)+\sum_{i=1}^{\infty}(1-\theta) \theta^{i} \beta^{i+1} \Lambda_{t, t+1+i}\left(1+r_{t+1+i}\right) z_{t, t+i} \\
\eta_{t}=(1-\theta) \beta \Lambda_{t, t+1}\left(1+r_{t+1}\right)+\beta \Lambda_{t, t+1} \theta z_{t, t+1} \sum_{i=0}^{\infty}(1-\theta) \theta^{i+1} \beta^{i+1} \Lambda_{t+1, t+2+i}\left(1+r_{t+2+i}\right) z_{t+1, t+1+i}
\end{gathered}
$$

The infinite sum at the right-hand size of equation (C.11) is one period updated version of equation (C.9), given by

$$
\eta_{t+1}=\sum_{i=1}^{\infty}(1-\theta) \theta^{i+1} \beta^{i+1} \Lambda_{t+1, t+2+i}\left(1+r_{t+2+i}\right) z_{t+1, t+1+i}
$$

where $z_{t+1, t+1+i}=\frac{n_{j t+1+i}}{n_{j t+1}}$

Hence, we can re-write equation (C.11) with the expectations as follows:

$$
\eta_{t}=E_{t}\left[(1-\theta) \beta \Lambda_{t, t+1}\left(1+r_{t+1}\right)+\beta \Lambda_{t, t+1} \theta z_{t, t+1} \eta_{t+1}\right]
$$

\section{Appendix C.2. Proof of Proposition 2}

The profit maximization problem by a representative bank is given by

$$
\begin{gathered}
V_{j t}=\max _{s_{j t}} E_{t} \sum_{i=0}^{\infty}(1-\theta) \theta^{i} \beta^{i+1} \Lambda_{t, t+1+i}\left[\left(r_{k t+1+i}-r_{t+1+i}\right) q_{t+i} s_{j t+i}+\left(1+r_{t+1+i}\right) n_{j t+i}\right] \\
\text { s.t. } V_{j t} \geq \lambda q_{t} s_{j t} \quad\left(\mu_{t}\right)
\end{gathered}
$$

where $\mu_{t}$ is the Lagrange multiplier associated with the incentive compatibility constraint. Using the solution for $V_{j t}$ in Proposition 2, I can re-write the intermediary's maximization problem using the Lagrangian,

$$
\mathrm{E}=\nu_{t} q_{t} s_{j t}+\eta_{t} n_{j t}+\mu_{t}\left[\nu_{t} q_{t} s_{j t}+\eta_{t} n_{j t}-\lambda q_{t} s_{j t}\right]
$$

The first order conditions w.r.t. $s_{j t}$ and $\mu_{t}$ are given respectively by

$$
\begin{gathered}
\left(1+\mu_{t}\right) \nu_{t} q_{t}=\mu_{t} \lambda q_{t} \\
V_{j t}-\lambda q_{t} s_{j t}=0
\end{gathered}
$$

Rearranging (C.17) gives us the following expression, 


$$
\nu_{t}=\frac{\mu_{t} \lambda}{\left(1+\mu_{t}\right)}
$$

Therefore, we establish that the incentive compatibility constraint binds $\left(\mu_{t}>0\right)$ as long as expected discounted marginal gain of increasing bank assets is positive. Replacing the definition of $\nu_{t}$, we obtain

$$
E_{t}\left[(1-\theta) \beta \Lambda_{t, t+1}\left(r_{k t+1}-r_{t+1}\right)+\beta \Lambda_{t, t+1} \theta \frac{q_{t+1} s_{j t+1}}{q_{t} s_{j t}} \nu_{t+1}\right]=\frac{\mu_{t} \lambda}{\left(1+\mu_{t}\right)}
$$

Imposing the steady-state, we get the following expression,

$$
\frac{(1-\theta) \beta\left(r_{k}-r\right)}{(1-\beta \theta)}=\frac{\mu \lambda}{(1+\mu)}
$$

Rearranging gives us

$$
\left(r_{k}-r\right)=\frac{(1-\beta \theta) \mu \lambda}{(1-\theta) \beta(1+\mu)}
$$

As long as $\mu$ is positive, i.e. the incentive compatibility constraint binds, risk premium is positive. Since I solve the model using linear approximation around the steady-state and the shocks are sufficiently small, the premium is always positive in numerical simulations.

\section{Appendix D. Competitive Equilibrium}

A competitive equilibrium of this model economy consists of sequences of allocations $\left\{c_{t}, L_{t}, K_{t+1}, s_{t}, n_{t}, \widetilde{n}_{t}, I_{t}, \eta_{t}, \nu_{t}, H_{t}\right\}_{t=0}^{\infty}$, of prices $\left\{w_{t}, r_{k t+1}, r_{t+1}, q_{t}\right\}_{t=0}^{\infty}$ and of exogenous processes $\left\{z_{t}, \omega_{t}\right\}_{t=0}^{\infty}$ such that (i) the allocations solve the household's, the firm's and the financial intermediary's problems at the equilibrium prices and (ii) markets for factor inputs clear. The following equilibrium conditions must be satisfied:

$$
\begin{gathered}
\frac{U_{l}(t)}{U_{c}(t)}=w_{t} \\
U_{c}(t)=\beta\left(1+r_{t+1}\right) E_{t} U_{c}(t+1) \\
r_{k t+1}=\frac{z_{t+1} F_{K}\left(K_{t+1}, H_{t+1}\right)+q_{t+1}(1-\delta)}{q_{t}}-1 \\
w_{t}=z_{t} F_{H}\left(K_{t}, H_{t}\right) \\
n_{t}=\omega_{t} \widetilde{n}_{t} \\
q_{t} s_{t}=\frac{\eta_{t}}{\lambda-\nu_{t}} n_{t} \\
\nu_{t}=E_{t}\left[(1-\theta) \beta \Lambda_{t, t+1}\left(r_{k t+1}-r_{t+1}\right)+\beta \Lambda_{t, t+1} \theta \frac{q_{t+1} s_{t+1}}{q_{t} s_{t}} \nu_{t+1}\right]
\end{gathered}
$$




$$
\begin{aligned}
& \eta_{t}=E_{t}\left[(1-\theta) \beta \Lambda_{t, t+1}\left(1+r_{t+1}\right)+\beta \Lambda_{t, t+1} \theta \frac{n_{t+1}}{n_{t}} \eta_{t+1}\right] \\
& \widetilde{n}_{t}=\theta\left[\left(r_{k t}-r_{t}\right) \frac{\eta_{t-1}}{\lambda-\nu_{t-1}}+\left(1+r_{t}\right)\right] n_{t-1}+\epsilon n_{t-1} \\
& q_{t} s_{t}=q_{t} K_{t+1} \\
& K_{t+1}=(1-\delta) K_{t}+\Phi\left(\frac{I_{t}}{K_{t}}\right) K_{t} \\
& q_{t}=\left[\Phi^{\prime}\left(\frac{I_{t}}{K_{t}}\right)\right]^{-1} \\
& L_{t}=H_{t} \\
& C_{t}+I_{t}=z_{t} F\left(K_{t}, H_{t}\right) \\
& \log \left(z_{t+1}\right)=\rho_{z} \log \left(z_{t}\right)+\epsilon_{t+1}^{z} \\
& \log \left(\omega_{t+1}\right)=\rho_{\omega} \log \left(\omega_{t}\right)+\epsilon_{t+1}^{\omega}
\end{aligned}
$$



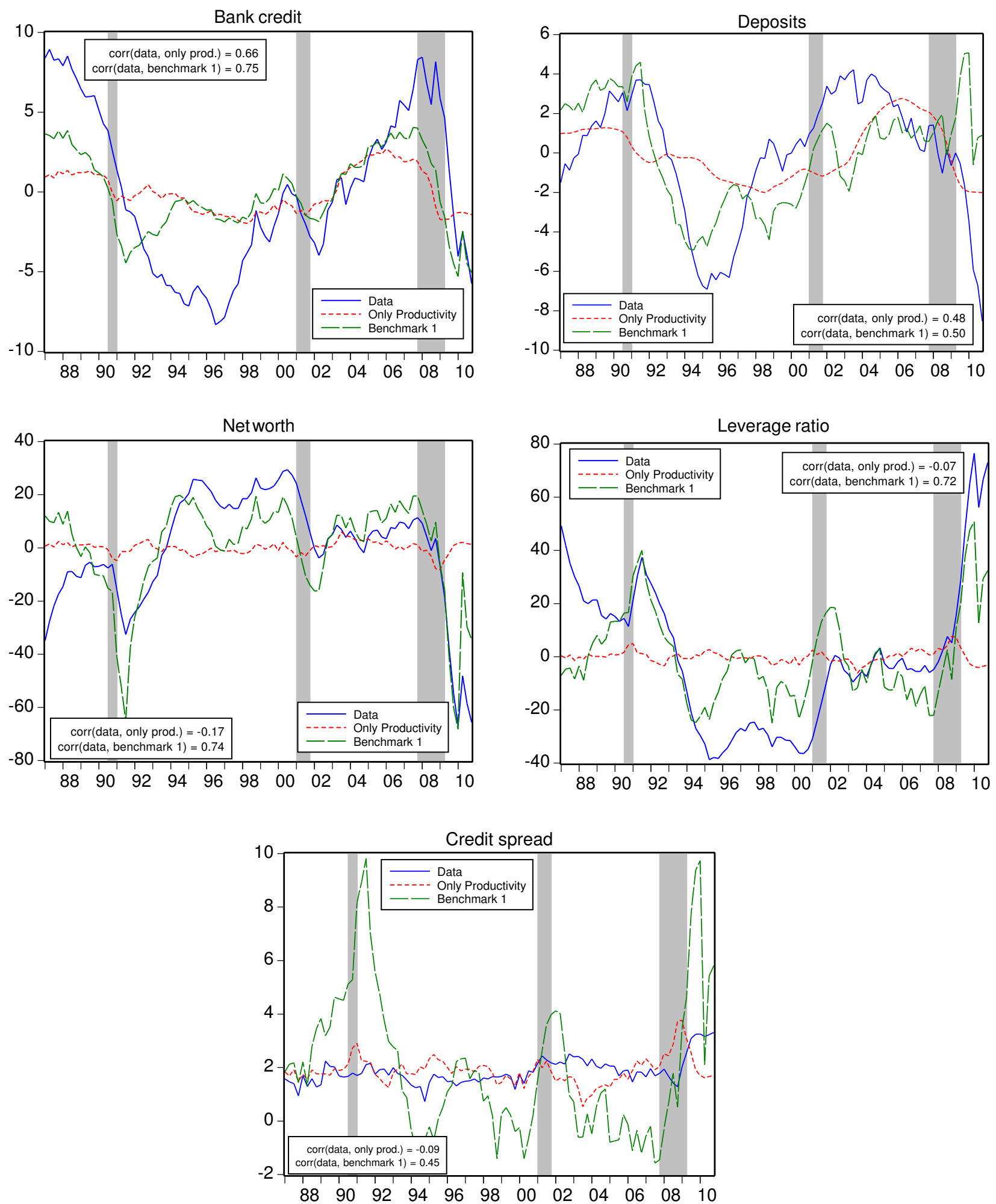

Figure 8: Financial Fluctuations: Benchmark vs. Only Productivity 


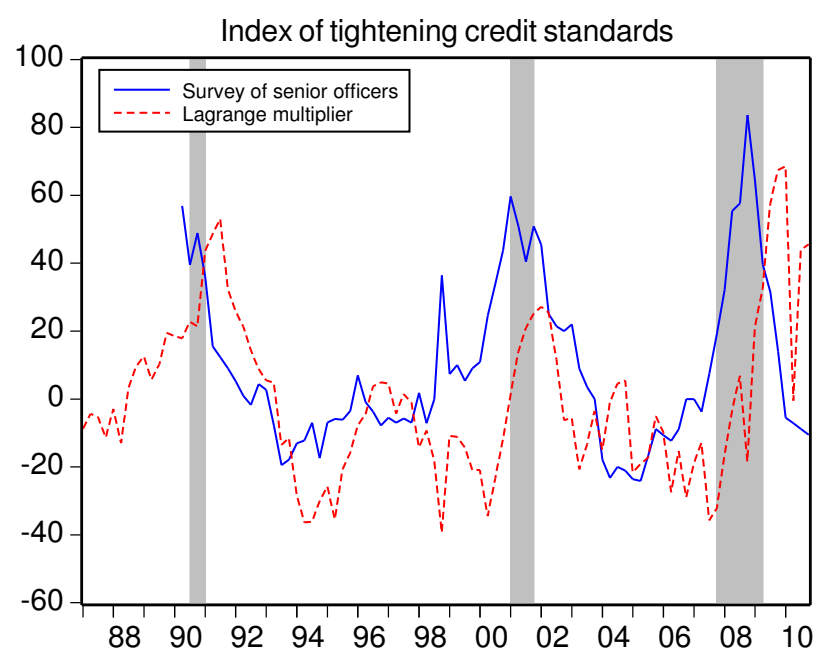

Figure 9: Tightness of Credit Conditions in the Benchmark Model 

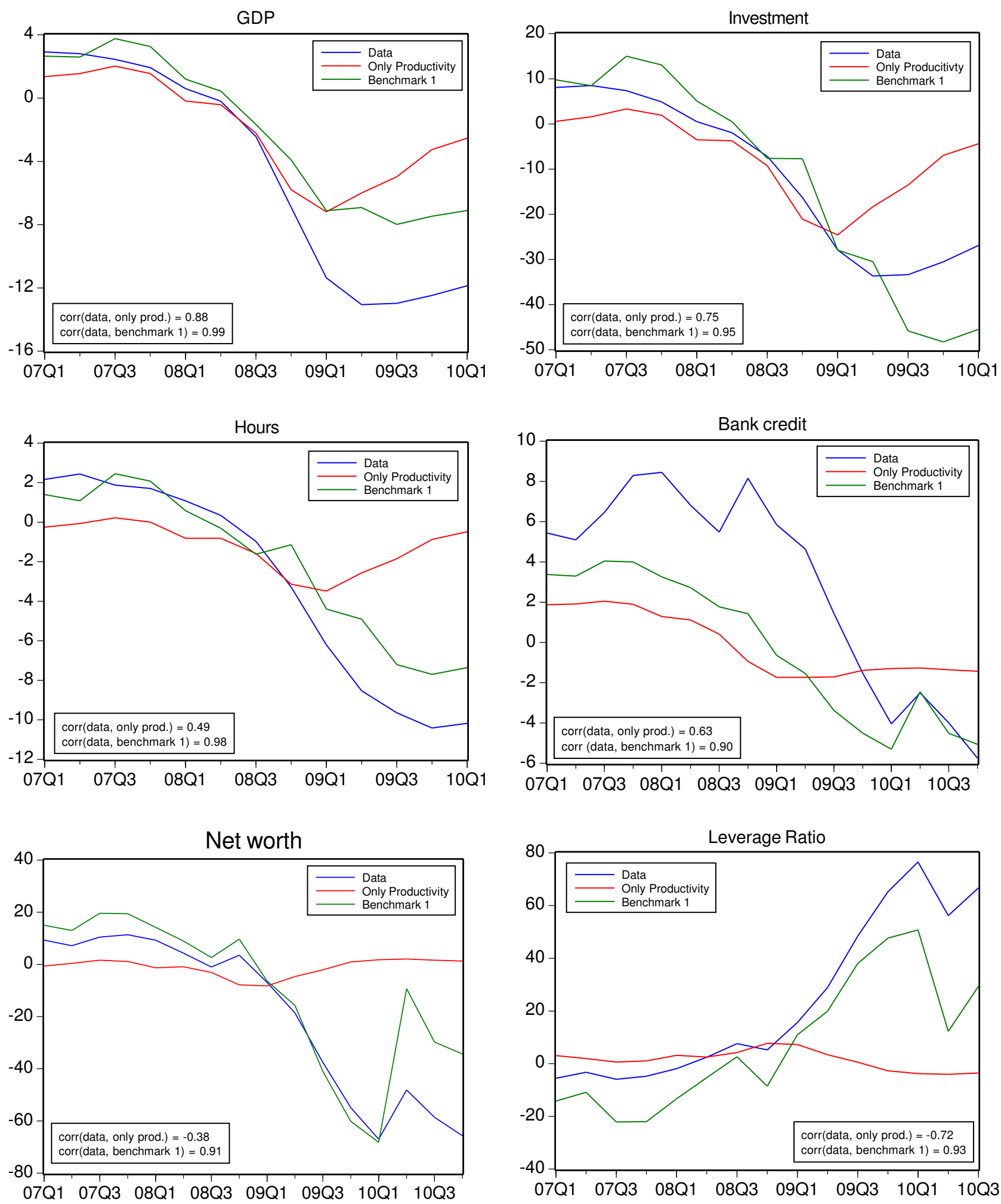

Figure 10: Real and Financial Fluctuations in 2007-09 Recession: Benchmark vs. Only Productivity 